\title{
Case Study \\ The Effects of Coping Cat Program on Anxiety, Emotion Regulation, and Resilience in Children Referring to Dentistry: A Case Study
}

\author{
${ }^{*}$ Liela Shakerimanesh ${ }^{1}$ (1), Fatemeh Hajiarbabi ${ }^{1}$ (C), Arash Peivandi Yazdi ${ }^{2}$ (1)
}

1. Department of Psychology, Graduate of Kavian Institute of Higher Education, Mashhad, Iran.

2. Lung Diseases Research Center, Mashhad University of Medical Sciences, Mashhad, Iran.

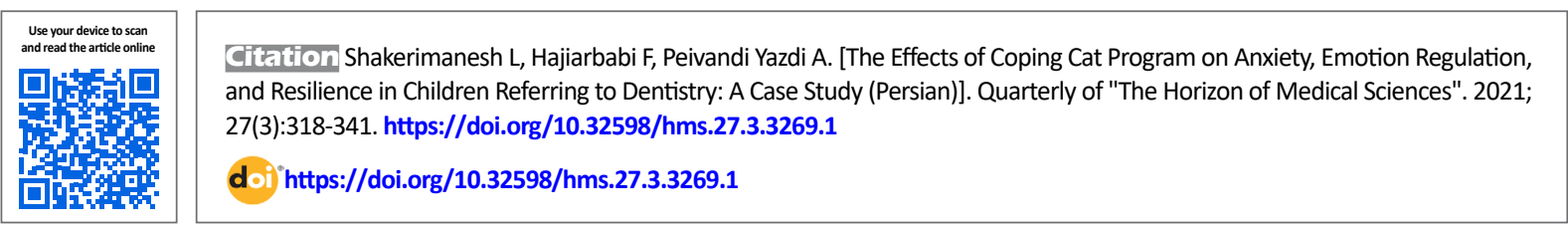

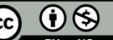

Received: 14 Oct 2019

Accepted: 09 May 2021

Available Online: $01 \mathrm{Jul} 2021$

Key words:

Coping cat program,

Anxiety, Emotion

regulation, Resilience,

Dentistry

\section{A B S TRACT}

Aims The number of pediatric dental clients is on the rise. Besides, the relevant methods are costly and concerning; therefore, psychological methods are required to treat pediatric dental anxiety. The current study aimed to evaluate the effects of the Coping Cat Program (CCP) on anxiety, Emotion Regulation (ER), and resilience among 7- to 12-year-old children.

Methods \& Materials This was a case study with multiple baselines and a one-month follow-up design. The research sample included 4 subjects referring to the dental clinic in Mashhad City, Iran, in May 2017. The study participants were selected by the purposive sampling method. The study subjects received 16 therapy sessions ( 2 weekly sessions) based on the CCP. The child version of the Cognitive Emotion Regulation Questionnaire (CERQ-k) and Spence Children's Anxiety Scale-Child (SCAS-Child) were used to collecting the required data. For data analysis, the graphical analysis method and the determination of recovery percentage were applied. The obtained data were analyzed using SPSS v. 21.

Findings Anxiety scores in the pretest and posttest in the first child ranged from 62 to 44 with the recovery rate of 0.29 ; in the second child, it ranged from 57 to 37 , with a recovery rate of 0.35 ; in the third child, it ranged from 48 to 35, with a recovery rate of 0.27 , and in the fourth child, this rate decreased from 55 to 25 with a recovery rate of 0.54 . Resilience scores in the pretest and posttest in the first child ranged from 52 to 75 , with a recovery rate of 0.44 , in the second child, it was from 43 to 66 , with a recovery rate of 0.53 ; in the third child, it ranged from 58 to 74 , with a recovery rate of 0.27 , and in the fourth child, it increased from 64 to 89 , with a recovery rate of 0.39 . ER components also significantly improved in the examined children.

Conclusion The present study data indicated that CCP was effective in reducing anxiety symptoms as well as increasing ER and resilience among children aged 7 to 12 years referring to dentistry. Thus, this method can be used to reduce anxiety symptoms and increase ER and resilience in this population. This method helps the child to become aware of negative thoughts, find evidence respecting their negative thoughts, cope with anxiety, learn skills, and practice and repeat these skills.

\section{* Corresponding Author:}

Liela Shakerimanesh

Address: Department of Psychology, Graduate of Kavian Institute of Higher Education, Mashhad, Iran.

Tel: +98 (513) 8583878

E-mail: shakeril@gmail.com 


\section{Extended Abstract}

\section{Introduction}

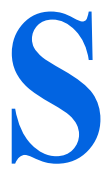

tatistics indicate that 1 in 5 children is afraid of the dentist [1]. The goal of pediatric dentistry is the prevention and treatment of oral diseases as a basis for favorable oral health throughout life. An essential reason for patients to refrain from referring to dental service centers and consequently increasing the deterioration of oral health is dental anxiety [2]. Dental anxiety, in the long run, reduces oral health and Quality of Life (QoL) and causes a high rate of social harm; eventually, this condition leads to untreated infection of the oral cavity. One approach to improve the level of oral health and improve the QoL is to study dental anxiety and its related factors [3]. If pediatric anxiety disorders remain untreated, they continue into adulthood; accordingly, they prolong the conditions and enhance healthcare costs [2].

Dental anxiety is a multifactorial phenomenon and various factors can affect the rate of anxiety. Three important relevant factors include hatred of the dental office, learning through role models, and personality [4]. These issues can prevent children from referring to the dentist and generate numerous adverse effects on their dental health. An underlying factor in mood and anxiety disorders is the inability to regulate emotions [5]. Numerous children with anxiety disorders manifest less Emotion Regulation (ER) skills. These children reported experiencing emotions much more severely, displaying dysfunction in ER, and using less adaptive coping strategies to improve their moods [6]. ER strategies refer to how individuals think after a negative event in life. ER plays an essential role in various negative and positive experiences; it is a method of coping with negative stimuli and unpleasant emotional experiences [7].

Another characteristic that helps a subject to adapt to a difficult life situation and protects individuals from the disorders and misfortunes of life is resilience [8]. Resilience is a positive adaptation in response to difficult situations. Resilience is achieved through resistance, self-enhancement, coping, and adopting positive moods and emotions [9]. Additionally, resilience is a form of self-healing with positive emotional and cognitive consequences. Hajdal et al. (1999) stated that individuals who scored high in resilience obtained the lowest level of depressive symptoms and anxiety. Resilience can guarantee and promote mental health in individuals [10].

Based on Cognitive-Behavioral Therapy (CBT) approaches, children's anxiety is rooted in various preoccupations with issues of concern, physical-arousal, and avoidance of new situations. Although different anxiety disorders can be found in childhood, it is generally agreed that the underlying structure of anxiety can respond to CBT [11]. Besides, the effectiveness of CBT in reducing anxiety symptoms is well established by research in children [12]. The first coherent program based on CBT to reduce children's anxiety was the Coping Cat Program (CCP) [13]. Based on the theoreticalcognitive-behavioral perspective, this program teaches anxious children the principles of anxiety and bodily reactions, corrects anxious self-talk, problem-solving, performance appraisal, and self-rewarding, and practices hierarchical coping with anxious situations with the help of these skills [14, 15].

CCP focuses on modifying thoughts, feelings, and behaviors, and combines beneficial behavioral strategies, such as coping, de-stress training, role-playing activities, practice, and reward with a double emphasis on cognitive information processing factors along with the anxiety of individuals and social forces. Zarghami [16] argued that "CCP effectively reduced anxiety symptoms, depression, concentration/hyperactivity disorder, physical, confrontational disobedience, and behavior of 8-10 Iranian children with generalized anxiety disorder, separation anxiety disorder, and social anxiety disorder. Santestban et al. [17] evaluated the effects of a shortterm CCP in children with anxiety at the Spanish Psychiatric Public Health Center. The relevant results revealed that the treatment was helpful and participants and caregivers reported satisfaction and a sense of security. Kendall, Fourer, and Poodle [18] suggested that CBT approaches for children with anxiety disorders have strong empirical support for children aged over 7 years. Clinical findings based on CCP suggested that $>60 \%$ of children have made significant progress after the intervention [6]. In a longitudinal study conducted by Dahlander et al. [19] to investigate the factors associated with dental fear and anxiety in children aged 7 to 9 years, the results suggested that $7 \%$ of 7 -year-old children experiences fear of dentistry with an average anxiety score of 9.22; the same rate in children aged 9 years equaled $8 \%$ with an average anxiety score of 25.4. Besides, the parental fear of dentistry, the experience of toothache, painful dental treatment, and caries between the ages of 7 to 9 years were significantly associated with dental anxiety in children [19]. Mehrstad et al. [20], as well as Abrahamson et al. [21], signified that dental anxiety was directly associated with unsatisfactory QoL. This type of anxiety was directly related to all social relationships and their mental states.

Considering that one approach to improve the level of oral health and the QoL is to study dental anxiety and its related factors. Furthermore, oral health depends on referring dentists for periodic examinations and treatment; therefore, the anxiety of pediatric dentistry is the focus of research in 
Iran. Thus, the present study aimed to investigate the effects of $\mathrm{CCP}$ on anxiety, ER, and resilience in children aged 7 to 12 years. The study results can be beneficial in the design and development of programs to educate families to eliminate pediatric dental anxiety and take appropriate actions when diagnosing oral diseases.

\section{Materials and Methods}

This research was reviewed in a single case design using baseline data. Sometimes, in educational and clinical environments, it is impossible to use group designs that require the repetition or elimination of the independent variables. High-Risk behaviors in the subjects, the small sample size, the special nature of the subjects, and the heterogeneity of the sample are the main reasons for the impossibility of using group designs. In cases where the researcher encounters ethical and practical constraints, single-case designs are used [22]. These designs, like experimental group designs with the active manipulation of the independent variable (treatment), allow cause and effect conclusions. Additionally, instead of using the control group in such designs, the position of the baseline acts as a controller for disturbing factors. Besides, the disturbing variables are controlled in the position of the baseline. The study population included all children aged 7 to 12 years in Mashhad City, Iran, who were referred to the dental clinic in May 2019. After referring to the dental clinic, 4 children with anxiety who received a high score on the anxiety questionnaire were selected by purposive sampling method according to the inclusion criteria. Then, a written informed consent form was obtained from the selected subjects' parents. The inclusion criteria of the research were being 7 to 12 years old, not receiving other treatment approaches in the past 6 months and during the training, and no biopsychological illnesses. The exclusion criteria were presenting biopsychological illnesses and receiving other psychological interventions before the treatment. The study subjects received a one-hour treatment program for 16 sessions (two days a week) (Table 1). The required data were collected at different stages of treatment and analyzed using SPSS v. 21. In the inferential section, the visual analysis method and recovery percentage were applied.

\section{Research tools included the following}

Emotional Cognitive Regulation Questionnaire-Children's Form: This questionnaire was developed by Garnowski and Karaj in 2006 in the Netherlands. It is used to identify individuals' cognitive strategies after experiencing challenging events [13]. It has 36 questions and consists of 9 subscales. The addressed strategies include the cognitive strategies of acceptance, positive refocusing, planning refocusing, positive reassessment, and perspective as adaptive strategies and self-blame, ruminant, catastrophic, and other-blame, as maladaptive strategies. The scale's scores range from 1 to 5 . Each subscale contains 4 items. The total score of each subscale is obtained by adding the score of the items, ranging between 4 and 20. In each subscale, the higher the individual score, the more they use the strategy. In Garnfsky's research, this tool's Cronbach's alpha coefficient was reported to range between 0.62 and 0.80 [13]; in Mashhadi et al.'s research [6], Cronbach's alpha coefficient of subscales of this questionnaire was obtained to range between 0.76 and 0.85 , suggesting its desirable reliability and validity.

Spence Children's Anxiety Scale: This is an anxiety assessment tool for children aged 15-8 years based on the Diagnostic and Statistical Manual of Mental Disorders, Fifth Edition (DSM-IV), i.e., developed in 1997 by Spence in Australia. This questionnaire has two versions of the child (45 items) and parent (38 items). Scoring is based on a 4-point Likerttype scale [never (0), sometimes (1), often (2), always (3)] and the 6 scales measure the following aspects: separation anxiety, social anxiety, obsessive-compulsive disorder, market phobia anxiety, general anxiety, and fear of bodily harm. The reliability of this scale was reported to be 0.92 for general anxiety and 0.60 to 0.82 for the subscales [24]. According to Mousavi et al. [25], the questionnaire's reliability was approved by Cronbach's alpha coefficient to range between 0.62 and 0.89 . Besides, 6 factors of the questionnaire were confirmed by the confirmatory factor analysis approach.

Angar and Liebenberg (2009) Child and Adolescent Resilience Scale: Angar and Liebenberg (2009) designed the Child and Adolescent Resilience Scale as a segregation tool for discovering the sources (individual, communication, contextual) of resilience. The scale consists of 28 items; respondents indicate their agreement with each item on a Likert-type scale, which ranges from absolutely (1) to very high (5), and 3 individual subscales of individual, communication, and contextual scale [26]. Kazeruni Zand, Shamloo, and Mirzaeian [27] reported the reliability of this questionnaire by Cronbach's alpha coefficient to range between 0.71 to 0.85 . These data indicate the good reliability of this questionnaire. Moreover, 6 factors of the questionnaire were confirmed by the confirmatory factor analysis method. The intervention program content was as follows:

\section{Results}

The study sample consisted of 3 boys and a girl who obtained a high anxiety score when referring to the dentist.

\section{First child: Ryan}

A 9-year-old boy whose anxiety episodes started in elementary school; currently visits the dental clinic and encounters extensive anxiety. He has never taken medication for anxiety. The 39-year-old mother is a housewife with a 
Table 1. Content of program coping cat

\begin{tabular}{|c|c|}
\hline Session & Treatment Content \\
\hline 1 & Communicating and getting acquainted with treatment goals \\
\hline 2 & $\begin{array}{l}\text { Identify the feelings of anxiety, help the child to recognize different emotions, and distinguish between the } \\
\text { feelings of anxiety and worry. }\end{array}$ \\
\hline 3 & Identify bodily reactions to anxiety. \\
\hline 4 & The first meeting with the parents. \\
\hline 5 & Familiarity with relaxation training and its use in reducing muscle tension associated with anxiety. \\
\hline 6 & Identify anxious self-talk and learn to challenge thoughts. \\
\hline 7 & An overview of anxiety self-talk and coping self-talk and developing problem-solving skills. \\
\hline 8 & Self-Assessment and self-reward training and a review of skills learned. \\
\hline 9 & The second meeting with the parents. \\
\hline 10 & Practice in situations with low anxiety using exposure assignments. \\
\hline 11 & Practice in situations where you are anxious, using exposure assignments. \\
\hline 12 & Practice coping tasks in situations with moderate anxiety. \\
\hline 13 & Teaching coping tasks in situations with moderate anxiety. \\
\hline 14 & Teaching coping tasks in situations with high anxiety. \\
\hline 15 & Teaching coping tasks when there is extensive anxiety. \\
\hline 16 & Practice coping tasks in situations of high anxiety, de-briefing, and finish treatment. \\
\hline
\end{tabular}

BA degree in software engineering, and a 40-year-old father who works as an electrical engineer. Ryan also had obsessive thoughts, such as always turning on an Xbox model or being careful not to step on the tile frame when walking (Figures 1 and 2). Comparing the scores of before treatment, 5 sessions after the treatment, 10 sessions after treatment, the end of the treatment, and the follow-up (one month after the treatment) in the first study subject reflected the effectiveness of the provided training program on increasing resilience, decreeing anxiety, and ER promotion in the first child. Furthermore, these changes continued until the follow-up phase.

\section{Second child: Arsam}

He was a 7-year-old boy who developed toothaches at the age of 5 years. He visited the dentist once and was unwilling to refer to the dentist to have his teeth cured due to his experience with anesthetic injections. The explored child's parents were very concerned about bringing their child to the dentist without all this anxiety. The 34-year-old mother had an MA degree in foreign languages and was employed (Figure 7 and 8). Besides, the child's 35-year-old father had a BA in chemistry and was employed. The child's parents worked well together to improve their child's anxiety (Figure 3 and 4).

Comparing the scores of before treatment, 5 sessions after the treatment, 10 sessions after the treatment, the end of the treatment, and the follow-up (one month after treatment) in the second study subject reflected the effectiveness of the $\mathrm{CCP}$ on increasing resilience, decreasing anxiety, and improving ER; this intervention also decreased the examined child's anxiety until the follow-up phase.

\section{Third child: Ronika}

She was a 9-year-old girl. Some of her baby teeth have not yet fallen out and should be removed at the dentist's discretion to replace them with the main teeth. However, due to Ronika's anxiety about dentistry, she had not been present since last year. Currently, she was referred to the dentist following her parent's insistence, and she was very restless. The mother was a 39-year-old, had a BA degree in computers, and was a housewife. Ronika's father was a 39-year-old employed civil engineer. A complaint of the 


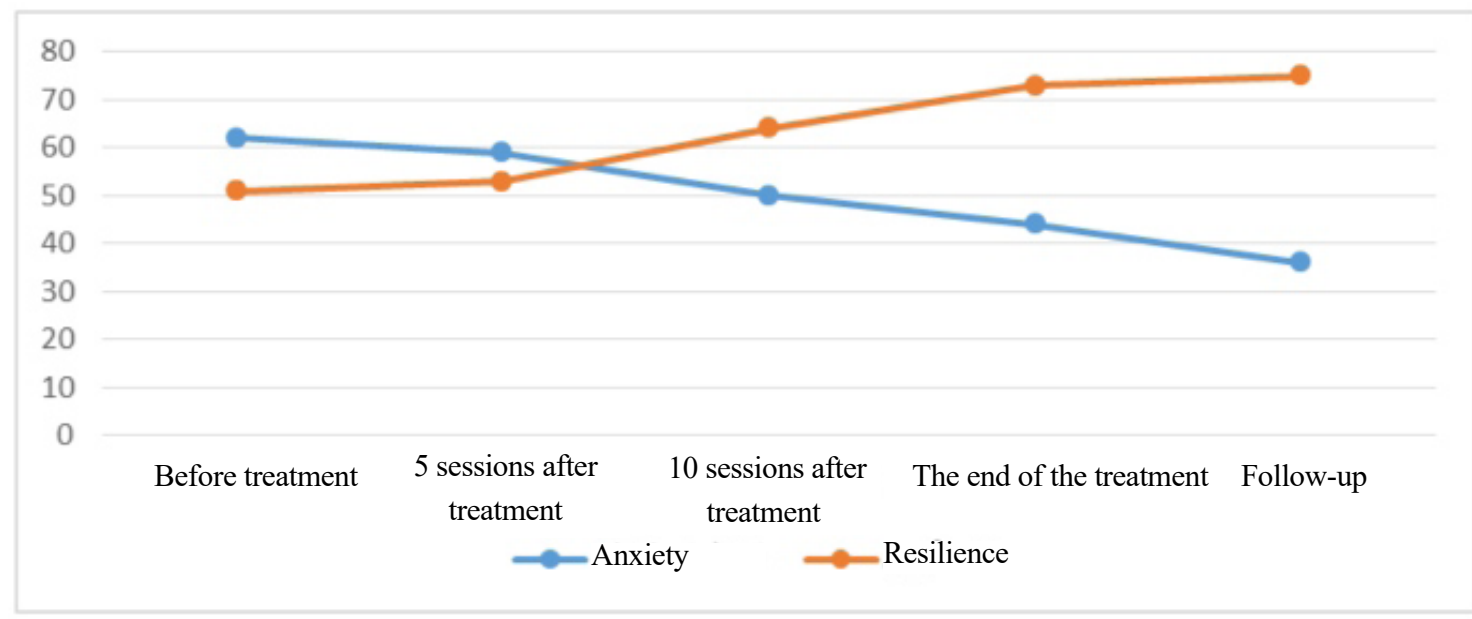

Quarterly of

The Horizon of Medical Sciences

Figure 1. Scores before treatment, 5 sessions after treatment, 10 sessions after treatment, the end of the treatment, and the follow-up of anxiety and resilience in the first study subject

mother was Ronika biting her nails, i.e., treated in the last sessions (Figure 5 and 6).

Comparing the scores of before treatment, 5 sessions after the treatment, 10 sessions after the treatment, the end of the treatment, and follow-up (one month after the treatment) in the third subject suggested the effectiveness of CCP on increasing resilience, decreasing anxiety, and increasing ER in the third child. Besides, the decreased anxiety and increased resilience values remained constant until the follow-up phase.

\section{Fourth child: Ali}

An 8-year-old boy who generated toothache for a while and did not visit the dentist and had a bad viewpoint about dentistry. He had visited a general dentist, and the first session, i.e., by injection, he was frightened and refused to visit a dentist, and was forcibly brought to the dentist by his mother. The 29-year-old mother had a BA in economics and was employed. Moreover, the 35-year-old father had an MA in economics and was employed.

Comparing the scores of before treatment, 5 sessions after the treatment, 10 sessions after the treatment, the end of

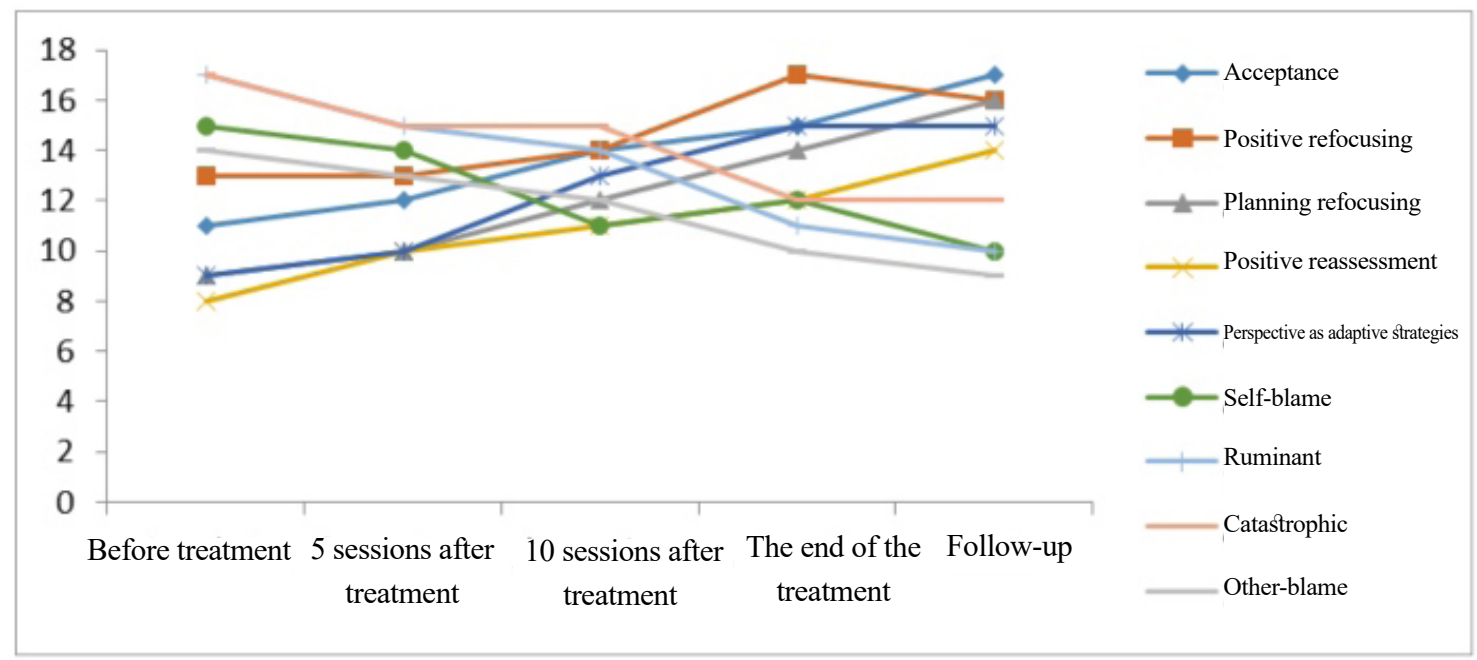

Quarterly of

The Horizon of Medical Sciences

Figure 2. The scores of before treatment, 5 sessions after treatment, 10 sessions after treatment, the end of the treatment, and the follow-up of ER components in the first research subject 


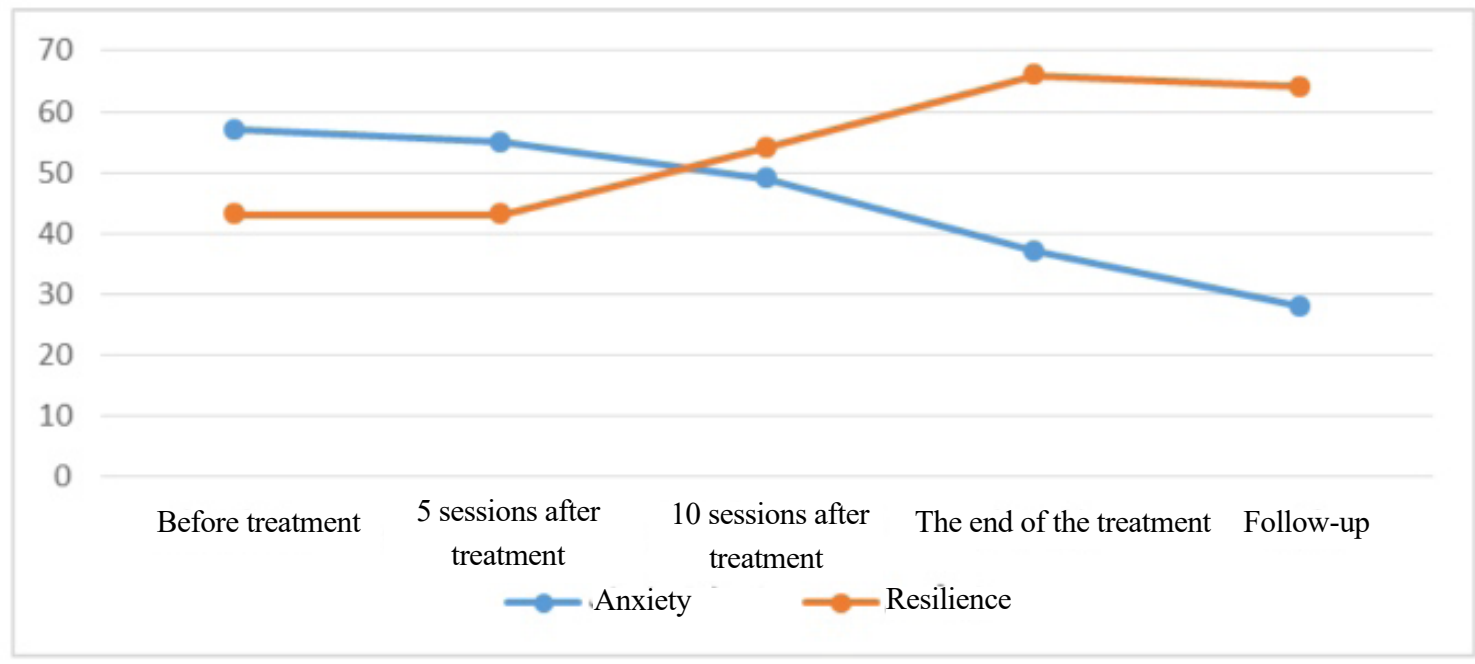

Quarterly of

The Horizon of Medical Sciences

Figure 3. The scores of before treatment, 5 sessions after the treatment, 10 sessions after the treatment, the end of the treatment, and the follow-up of anxiety and resilience in the second research subject

the treatment, and the follow-up (one month after the treatment) in the fourth study subject reflected the effectiveness of CCP on increasing resilience, reducing anxiety, and enhancing ER in the fourth child. The decreased anxiety and increased resilience remained until the follow-up phase in this child. As per Tables 2 and 3, anxiety and resilience, as well as all components of ER were significantly improved post-treatment, indicating the effectiveness of CCP on improving anxiety, resilience, and ER in children; this increase remained until the follow-up phase.

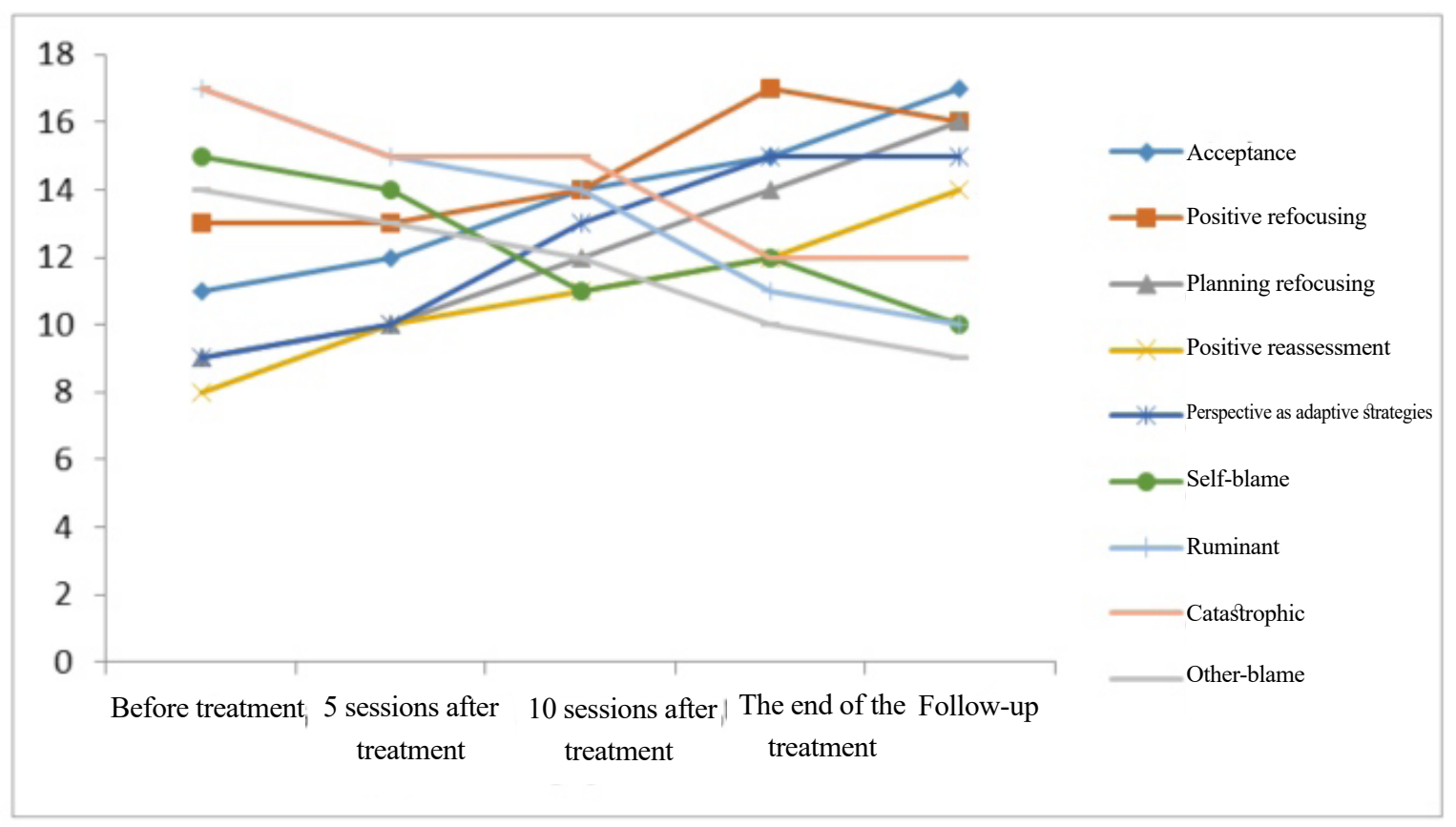

Quarterly of

The Horizon of Medical Sciences

Figure 4. The scores of before treatment, 5 sessions after the treatment, 10 sessions after the treatment, the end of the treatment, and the follow-up of ER components in the second study subject 


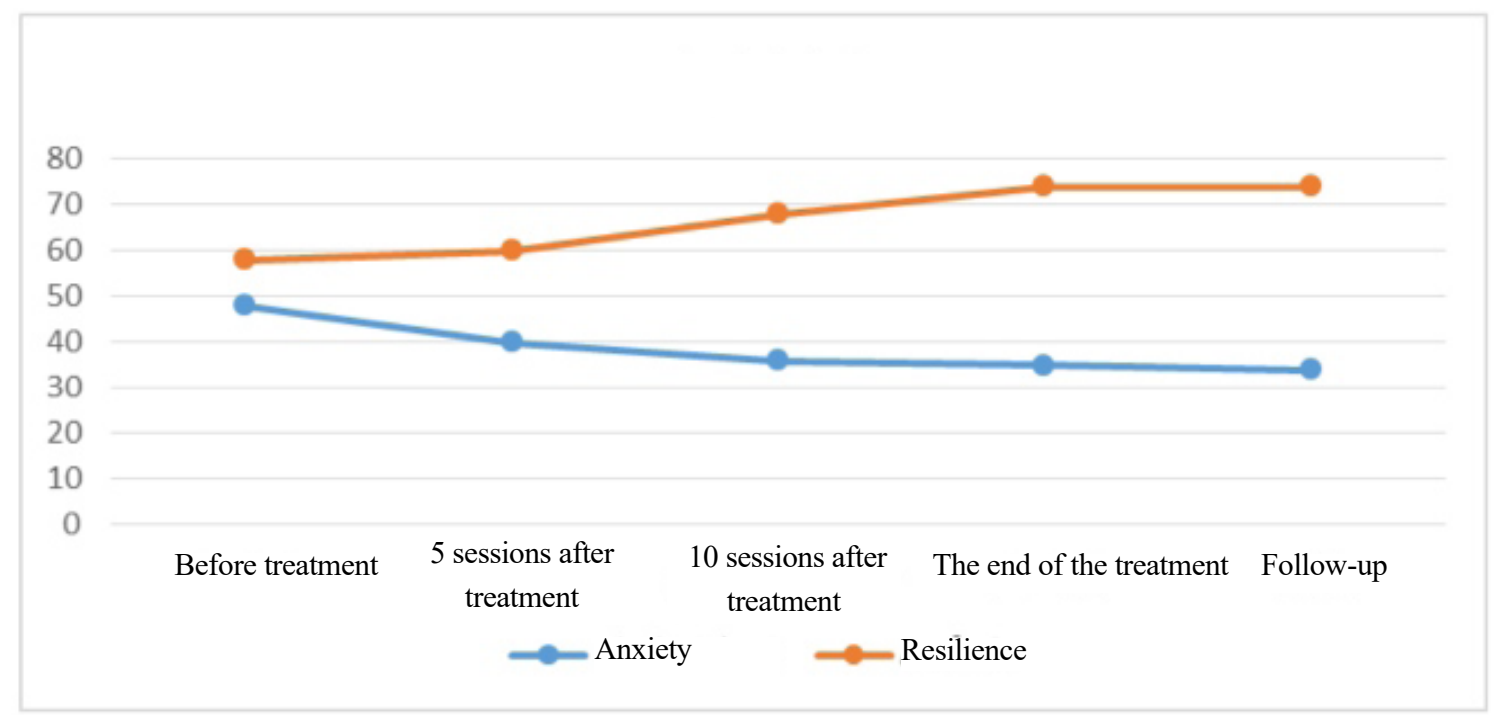

Quarterly of

The Horizon of Medical Sciences

Figure 5. The scores of before treatment, 5 sessions after the treatment, 10 sessions after the treatment, the end of the treatment, and the follow-up of anxiety and resilience in the third study subject

\section{Discussion}

Fear and anxiety present various effects on children's lives. Among the anxieties and fears of children is the fear of the dental environment; this condition is manifested in the form of negative behaviors (e.g., fear, anxiety, pain, \& anger) during the examination. This study examined the effects of CCP on anxiety, ER, and resilience in children aged 7 to 12 years referring to dentistry. The relevant results suggested that CCP improved anxiety, resilience, and ER in the explored children. The obtained findings were consistent with those of previous studies, such as Mir Hosseini, Alizadeh and Farrokhi [28], Dahlander et al. [19], Birjandi, Mashhadi, Tabibi [6], Kendall, Fourier, and Poodle [18], Compton et al. [29], Smith [30], Santest Ban et al. [17], as well as Nook and associates [31]. In the CCP, children learn how to evaluate their assessment process, i.e., rooted in their misconceptions of low self-efficacy and high stress-

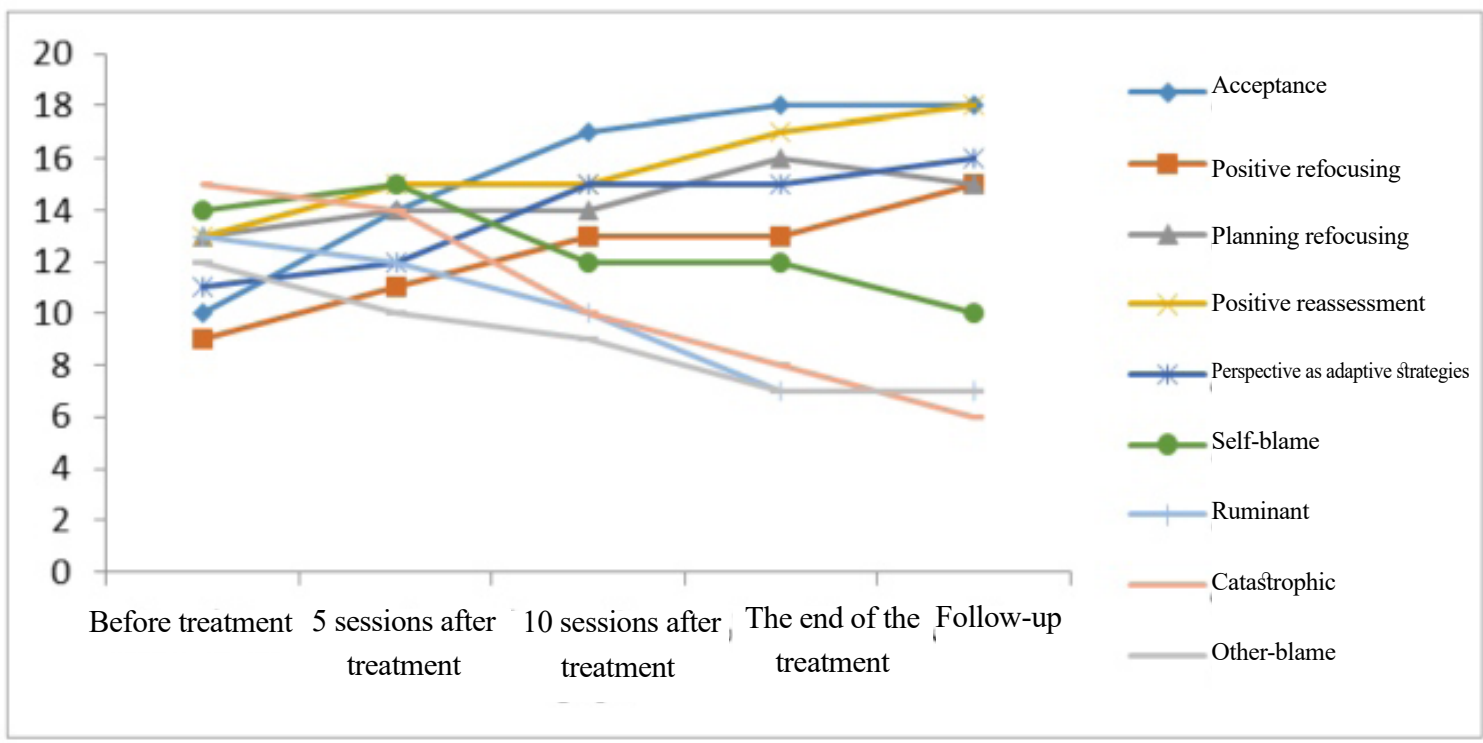

Quarterly of

The Horizon of Medical Sciences

Figure 6. The scores of before treatment, 5 sessions after the treatment, 10 sessions after the treatment, the end of the treatment, and the follow-up of ER components in the third study subject 


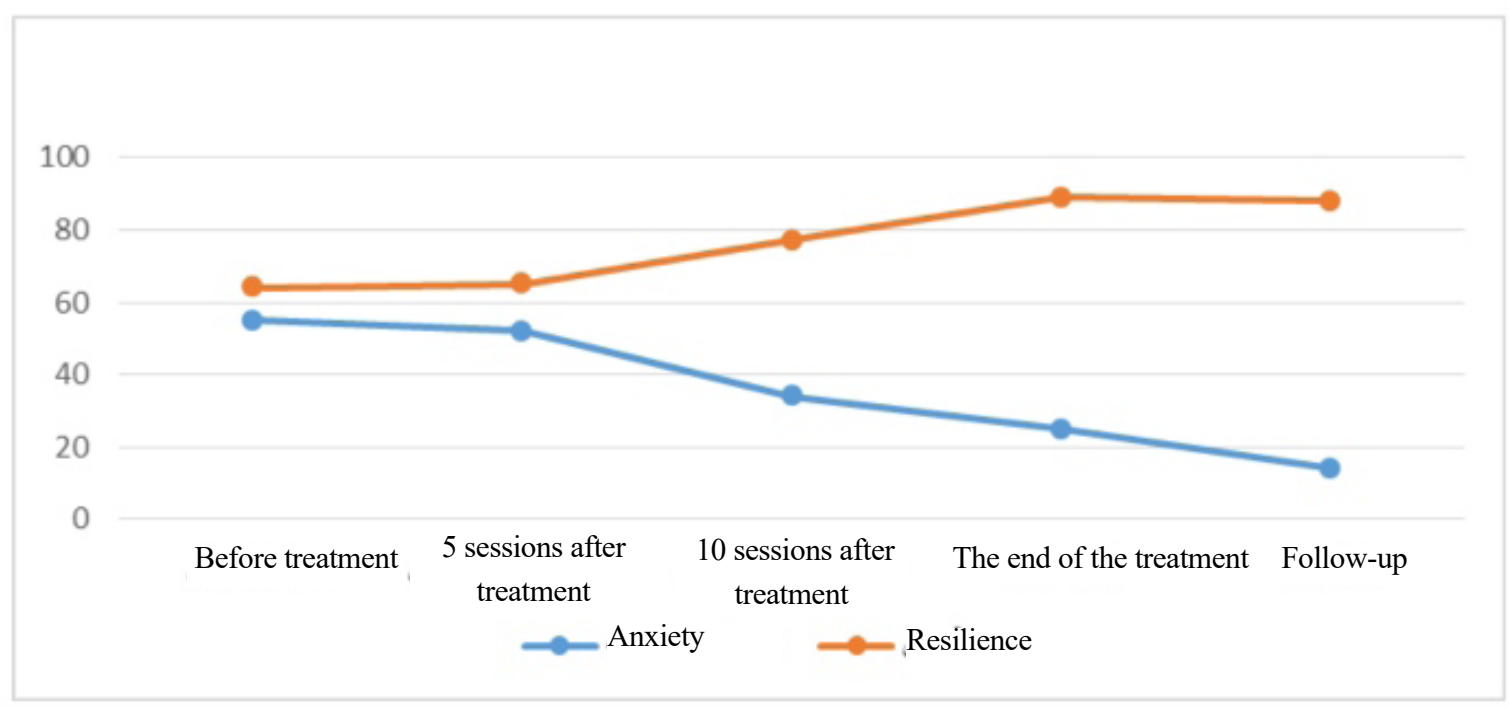

Quarterly of

The Horizon of Medical Sciences

Figure 7. The scores of before treatment, 5 sessions after the treatment, 10 sessions after the treatment, the end of the treatment, and the follow-up of anxiety and resilience in the fourth research subject

ful situations; by learning treatment skills, a plan for coping, and thinking about different solutions, cognitive reconstruction, and correcting cognitive avoidances; by correcting this self-talk, align their abilities with the nature of stressful situations; ultimately help boost their self-confidence by confronting (rather than avoidance) [32].

Accordingly, the techniques used in this treatment method are as follows: identifying the feelings of anxiety and bodily reactions, relaxation, reviewing and changing anxiety selfexpression, problem-solving, performance appraisal, and practicing hierarchical exposure to anxious situations has an entertaining approach to therapy. Besides, it helps the child find negative thinking patterns, examine the relationship between thought and feeling and action, find evidence for negative thoughts, learn skills to cope with anxiety, and practice and repeat these skills. The child is in a state of escape-struggle when confronted with stress; thus, they must identify negative thoughts, feelings, and emotions, such as anxiety, worry, threat, helplessness, danger, and insecurity. Emotional awareness is a process of attention, i.e., associated with interpretive and valuable functions. Each treatment can lead to treatment through its special components;

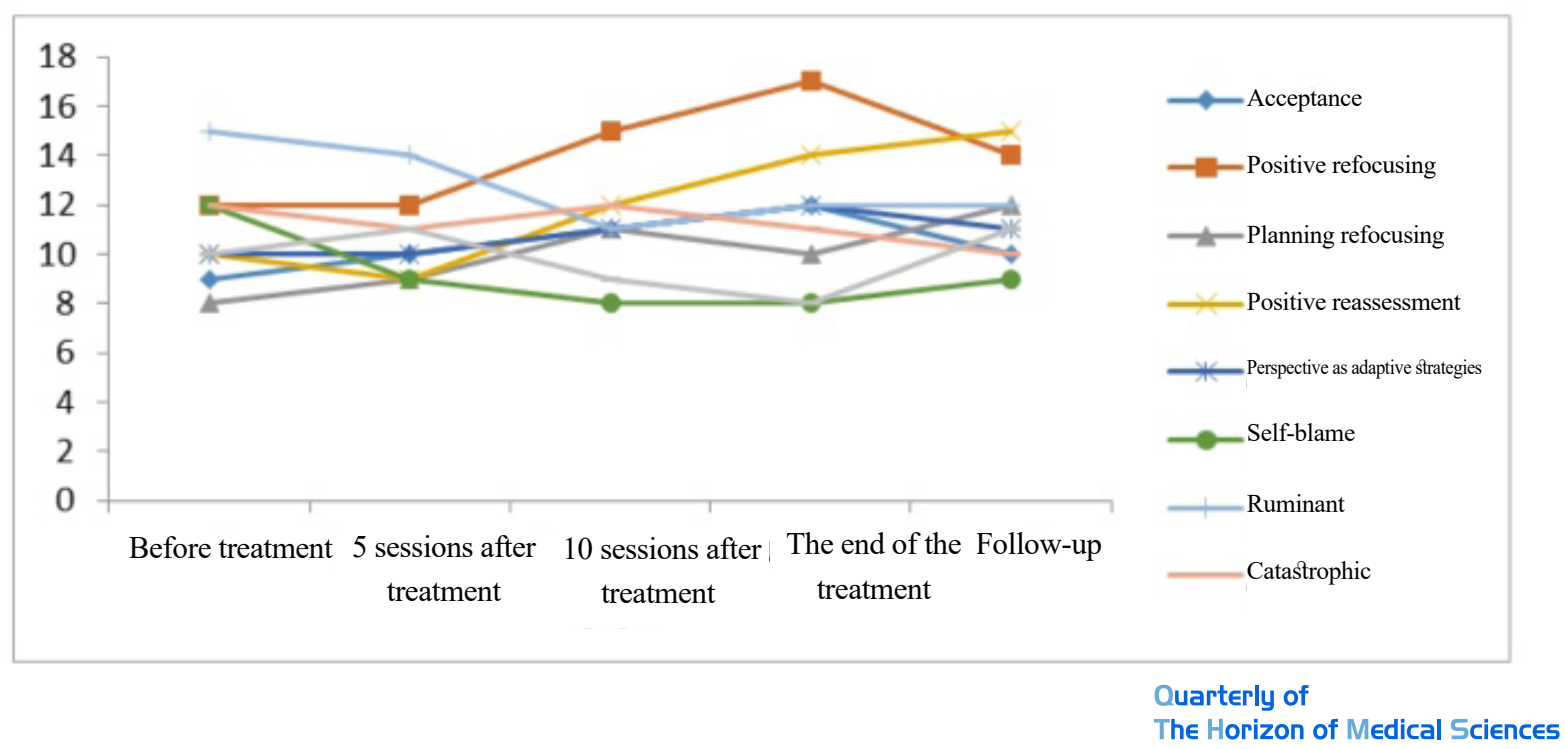

Figure 8. The scores of before treatment, 5 sessions after the treatment, 10 sessions after the treatment, the end of the treatment, and the follow-up of ER components in the fourth subject 
Table 2. The results of effect size in the end stages of treatment and follow-up concerning anxiety and resilience

\begin{tabular}{|c|c|c|c|}
\hline \multirow{2}{*}{ Subjects } & \multirow{2}{*}{ Stage } & \multicolumn{2}{|c|}{$\%$} \\
\hline & & Anxiety & Resilience \\
\hline \multirow[b]{2}{*}{ First } & The end-stage of treatment & 29 & 44 \\
\hline & Follow up & 41 & 46 \\
\hline \multirow{2}{*}{ Second } & The end-stage of treatment & 35 & 53 \\
\hline & Follow up & 50 & 48 \\
\hline \multirow{2}{*}{ Third } & The end-stage of treatment & 27 & 27 \\
\hline & Follow up & 29 & 24 \\
\hline \multirow{2}{*}{ Fourth } & The end-stage of treatment & 54 & 39 \\
\hline & Follow up & 74 & 37 \\
\hline
\end{tabular}

the CCP, by teaching the treatment pattern (teaching the relationship between thoughts, feelings, \& behaviors) identifying thought patterns (recognizing thoughts in different situations), detecting cognitive distortions (the awareness of cognitive distortion \& its types), evaluating thoughts and improving the process of cognitive change and encouraging cognitive reconstruction, learning new cognitive skills, emotion management (teaching relaxation \& controlled deep breathing), reduce children's anxiety. These components, with the changes they make in the individual's thinking and behavior, facilitate adapting to new conditions and creating new skills in the child [16].
In this treatment program, by teaching the effect of negative thoughts and anxious self-talk on emotions and behavior, the child understands the relationship between negative and catastrophic thoughts and feeling anxiety. Using cognitive techniques, such as identifying negative self-talk and catastrophic thoughts and challenging them and replacing more real self-talk and using better-coping skills, and using it in a threatening situation, leads to increased adaptive cognitive strategies for ER. Furthermore, these skills helped the child to use adaptive coping and adaptive ER. Moreover, among the components of ER, planning has the highest frequency of improvement. Besides, the percentage

Table 3. Baseline, treatment, and follow-up scores of the ER

\begin{tabular}{ccc}
\hline Scale & The Percentage of Recovery After Treatment & The Percentage of Improvement in Follow-up \\
\hline The reception & 0.35 & 0.45 \\
\hline Positive refocusing & 0.43 & 0.36 \\
\hline Planning & 0.57 & 0.57 \\
\hline Positive re-evaluation & 0.23 & 0.37 \\
\hline Perspective & 0.47 & 0.38 \\
Self-Blame & 0.19 & 0.26 \\
Ruminant & 0.37 & 0.36 \\
Catastrophic & 0.44 & 0.45 \\
\hline Other-Blame & 0.32 & 0.44 \\
\hline
\end{tabular}


of perspective improvement, positive refocus, and rumination decreased in the follow-up stage.

To provide another explanation, we can refer to the studies of Gross and Thompson in this regard, as follows: using positive ER strategies modulates the effect of assessments and mental reactions of individuals in the face of stressful events. Moreover, it leads to appropriate cognitive, motivational, and behavioral responses in such situations. This treatment program has reduced the implementation of maladaptive ER strategies in children with anxiety; this was achieved by challenging various cognitive errors and teaching effective coping strategies and self-talk, i.e., consistent with reality. The CCP combines a set of effective behavioral approach techniques (e.g., coping with homework, relaxation training, role-playing, practice, \& reward) and techniques for modifying cognitive factors that affect the information processing of anxious subjects. The program also introduces a logical combination of emotion perception and emotion management skills. This is because social stress management (e.g., family \& peer pressure) is also associated with these skills. This treatment program has helped to increase children's resilience by teaching muscle relaxation exercises, deep breathing techniques, and effective training.

A limitation of this research was its sample size. This was single-case research and the sample size equaled 4 children; thus, care should be taken in generalizing the results. Another research limitation concerned the research tool, i.e., only a questionnaire and using a tool may not restrict collecting accurate information. Given the importance of interdisciplinary and the interaction of many specialized sciences and professions, and that pediatric dentistry is a discipline related to psychology, there are different behavioral control methods for treating pediatric anxiety, ranging from talking to the child to relaxation techniques with medications and general anesthesia, i.e., highly costly. The cooperation of psychologists with the dental team and the use of the CCP are recommended to reduce the behavioral confusion caused by pediatric dental treatment. It is also suggested that training based on the coping cat program be considered in the context of group schemes.

\section{Conclusion}

The current study data indicated that CCP can reduce the severity of anxiety caused by dental treatment and increase resilience and ER in children. Therefore, it is recommended to use this program to reduce anxiety among children who refer to dental services; this method can significantly reduce the severity of children's anxiety.

\section{Ethical Considerations}

\section{Compliance with ethical guidelines}

This research plan was presented at the meeting of the Regional Ethics Committee in the Biomedical Research Department of Mashhad University of Medical Sciences in February 2020. It was stated in a letter that this plan did not contradict the principles of ethical research in this article.

\section{Funding}

The present article was extracted from the MA. thesis of first author at the Educational Psychology, Kavian Institute of Higher Education, Mashhad.

\section{Authors' contributions}

All authors equally contributed to preparing this article.

\section{Conflicts of interest}

The authors declared no conflict of interest. 
This Page Intentionally Left Blank 


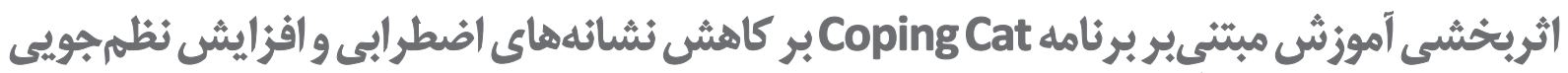

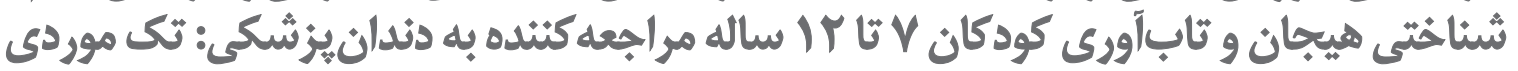

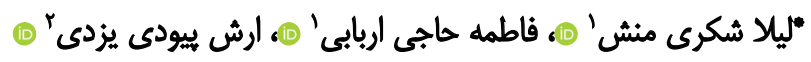

ا. ا.تروه روانشناسى، مؤسسه آموزش عالى كاويان، مشههد ايران.

r. مركز تحقيقات بيمارى هاى ريه، دانشعاه علوم يزشكى مشهله مشهيد، ايران.

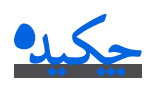

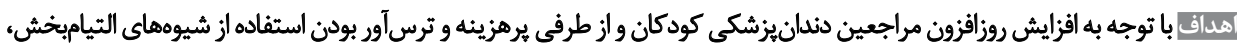

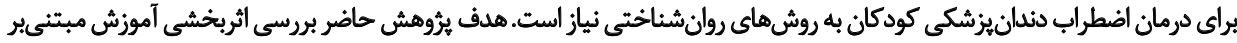

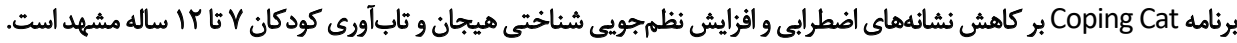

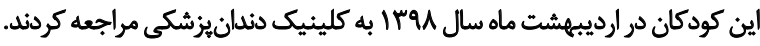

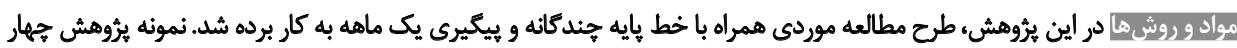

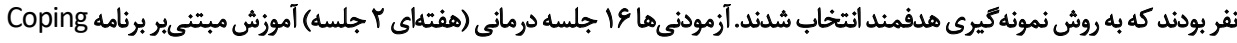

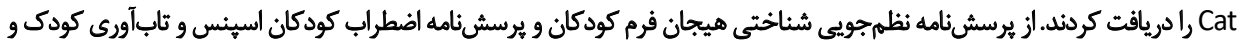

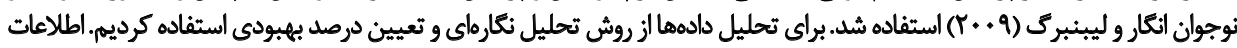

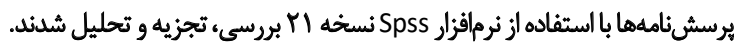

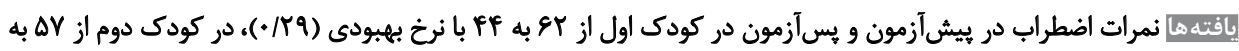

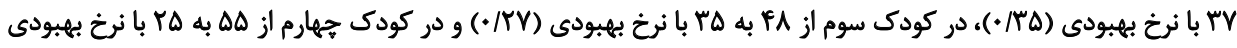

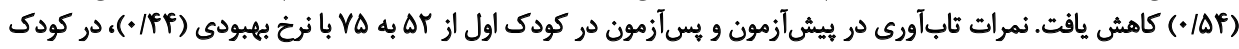

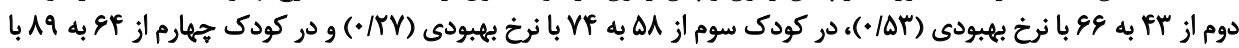

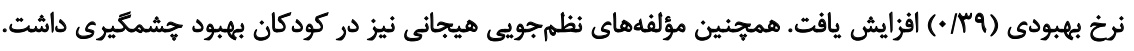

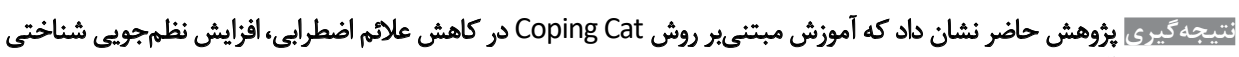

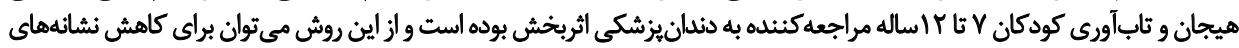

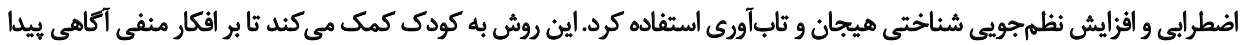

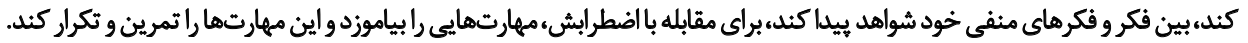

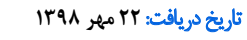

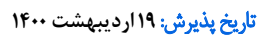

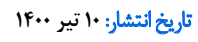

كليدواروها:

آموزش مبتنىبر برنامه (C) Coping Cat

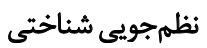

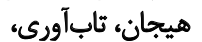

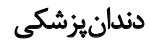

ميى كاهد، آسيب اجتماعى زيادى رابه همر اه دارد و در بايان سبب إنقان

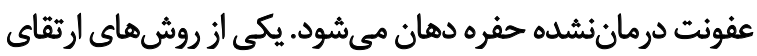

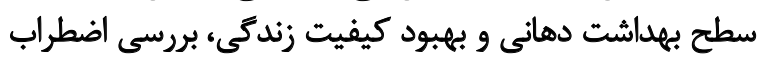

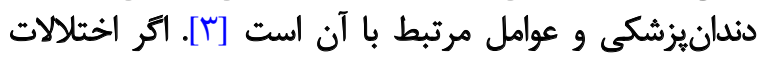

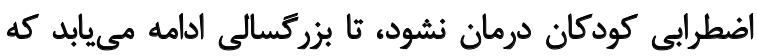

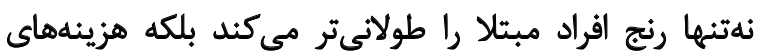

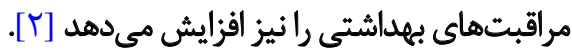

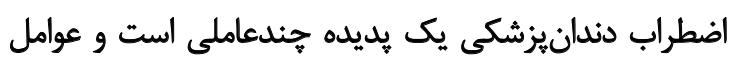

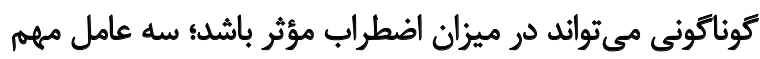

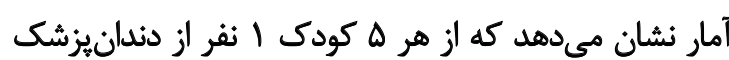

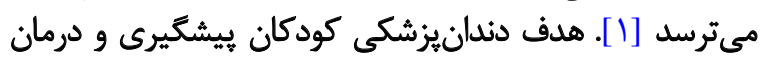

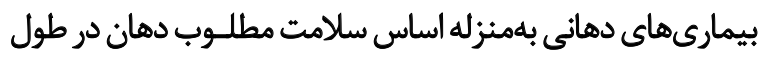

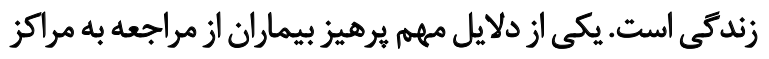

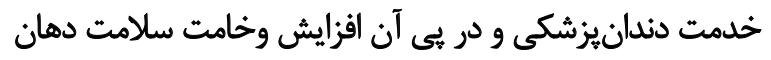

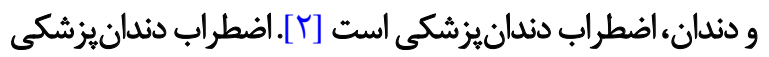

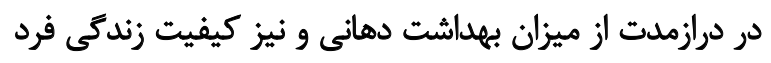
둔.

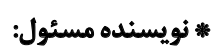

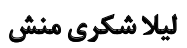

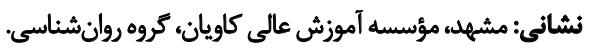

تلفن:

يست الكترونيكي: shakeril@gmail.com 
تغيير فكر، احساس و رفتار متمركز است و تركيبى از راهبردهاى

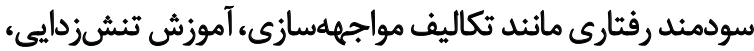

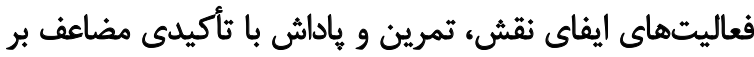

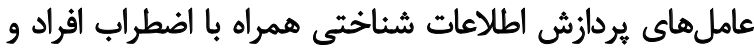

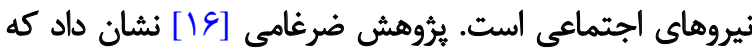

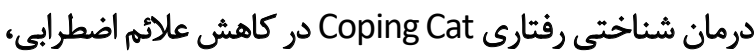

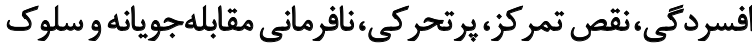

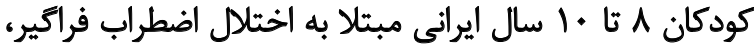

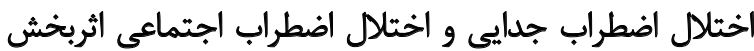

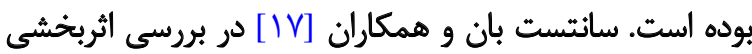

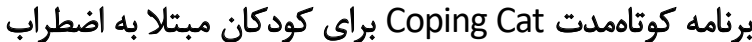

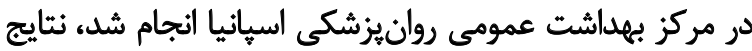

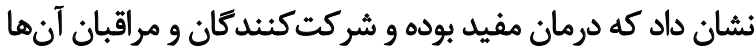

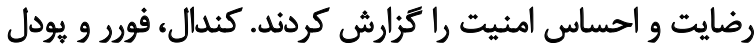

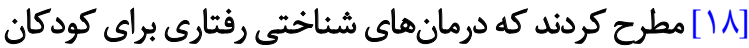

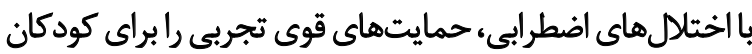

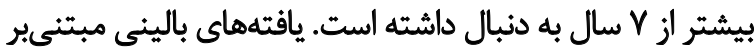

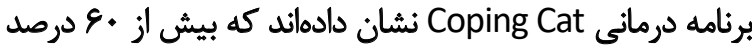

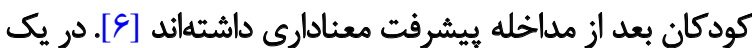

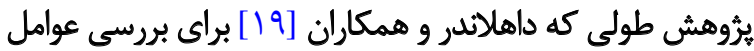

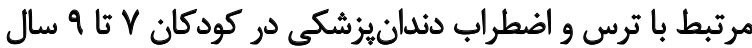

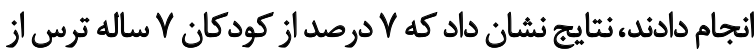

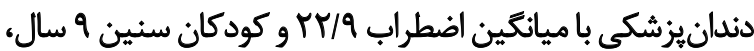

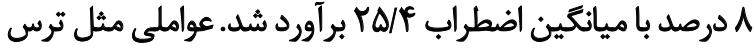

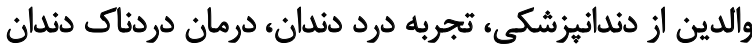

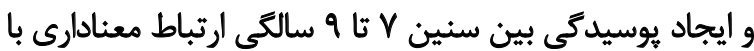

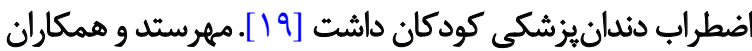

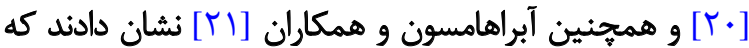

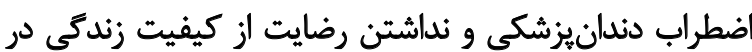

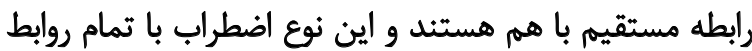
اجتماعى و حالتهاى روانى آنها رابطه مستقيم دارد. با توجه به اينكه يكى از روشهاى ارتقاى سطح بهداشت

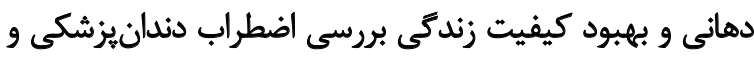

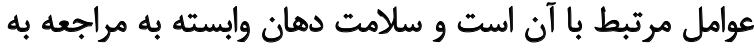

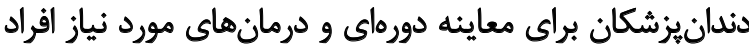

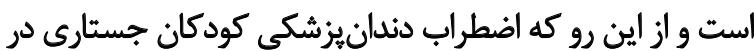

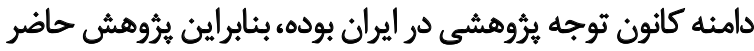

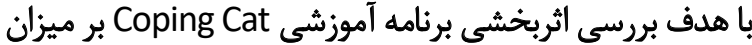

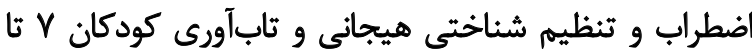

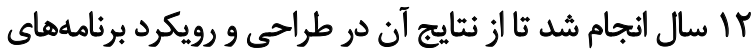

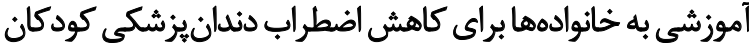

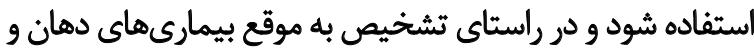

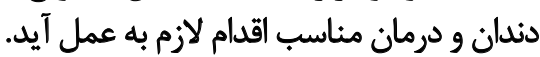

شامل: نفرت از مطب دندانيزشكى، يادكيرى از طريق نقش

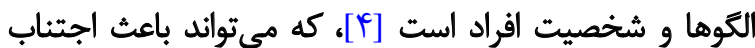

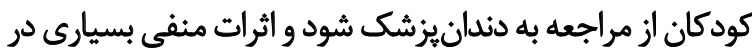

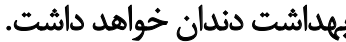

يكى از عوامل زيربنايي در اختلالات خلقى و اضطرابي، ناتوانى إنى إنيات

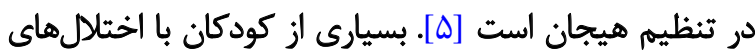

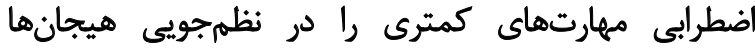
نشان ميدهند. به طورى كه اين كودكان كزارش كرئ كردند

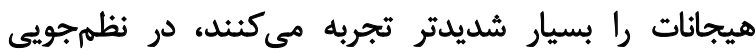

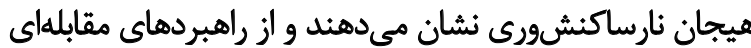

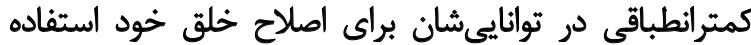

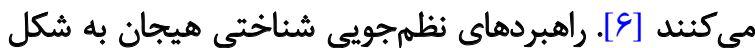

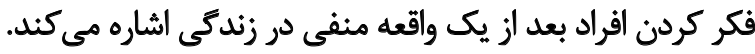
نظمجويى شناختى هيجان در تجارب كوريك

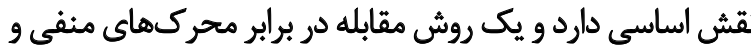

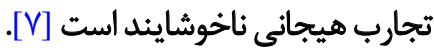
يكى ديكر از عواملى كه به فرد در سازكارى با موقعيت دشوار

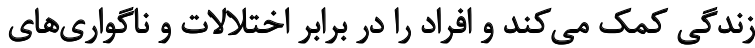

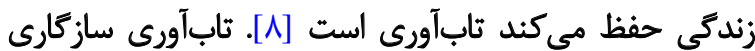

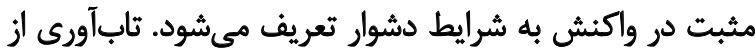

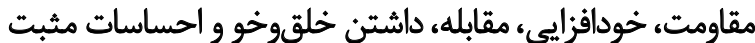

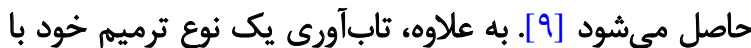

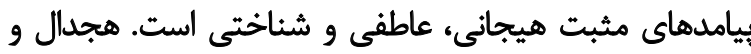

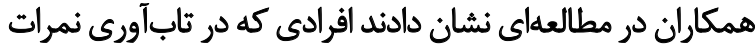

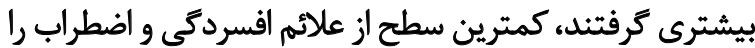

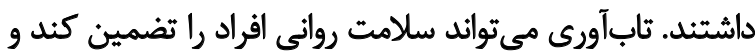

آن را ارتقا دهد [• [1].

برمبناى رويكردهاى شناختى رفتارى، اضطراب كودكان ريشه

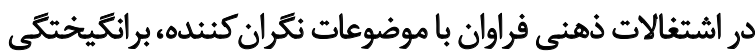

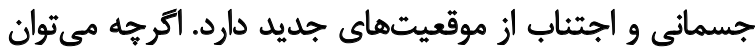

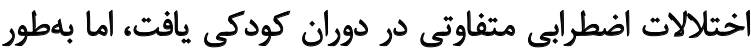

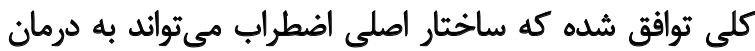

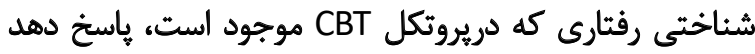

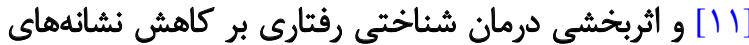

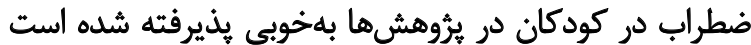

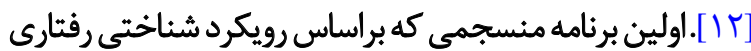

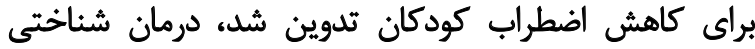

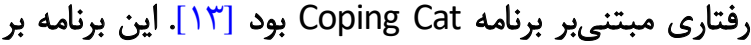

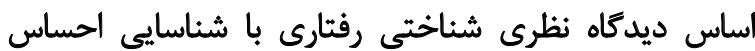

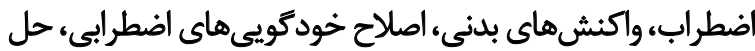

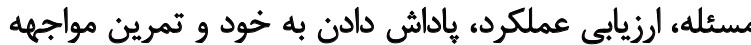

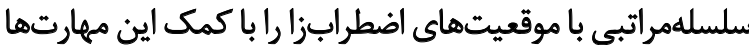

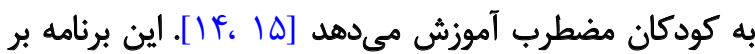




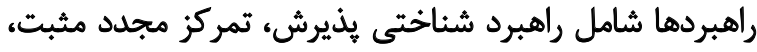

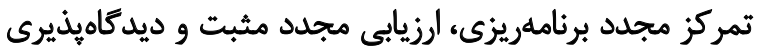

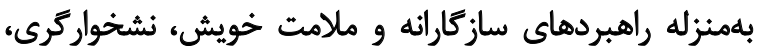

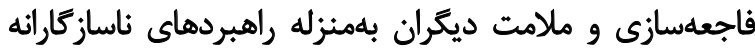

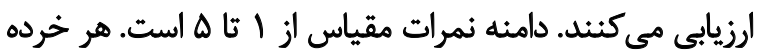

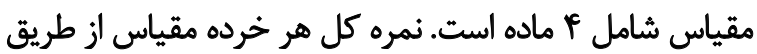

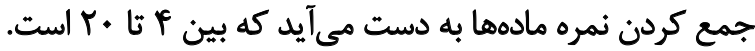

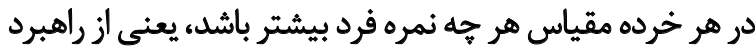

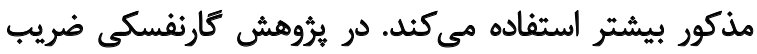

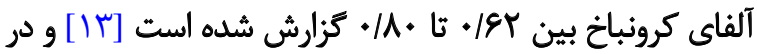

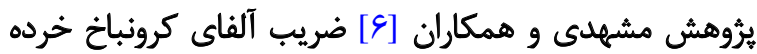

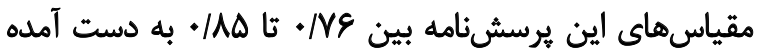

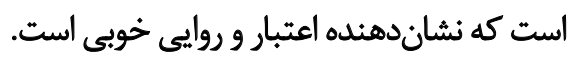

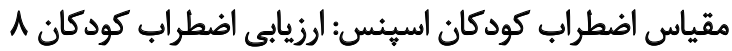

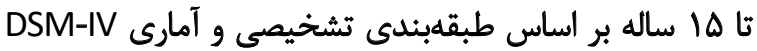

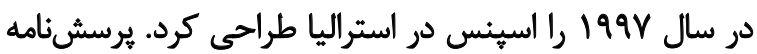

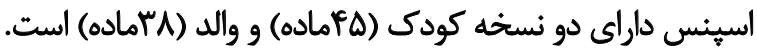

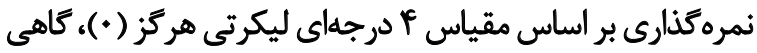

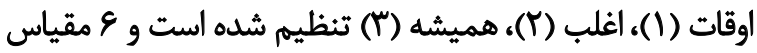

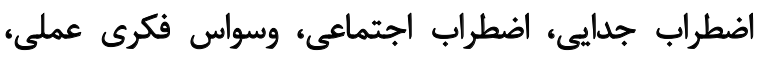

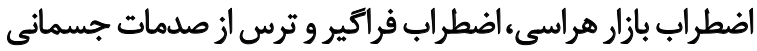

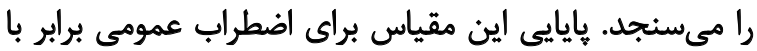

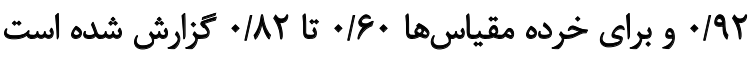

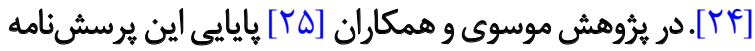

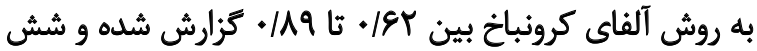
عامل يرسشنامه، با تحليل عامل تأييدى، تأييد شدند. تئن

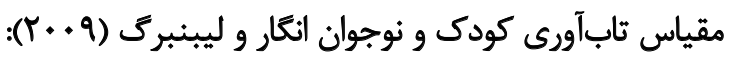

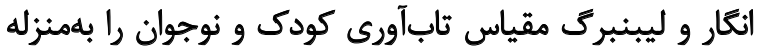

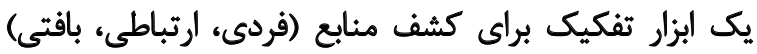

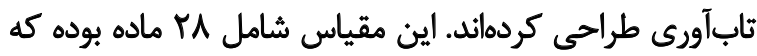
هإسخدهند

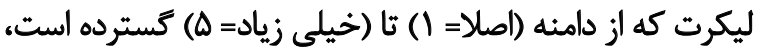

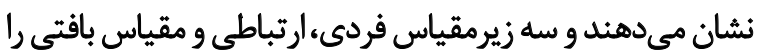

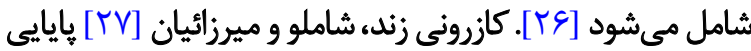

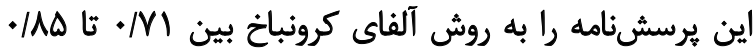

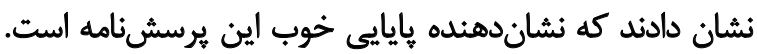

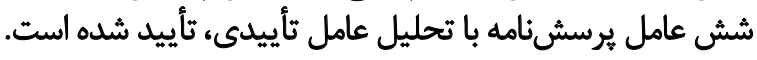

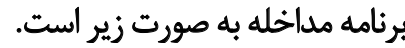

يافتهها

نمونه مطالعه شامل سه يسر و يك دخت دختر است كه در هنتام مراجعه به دندانيزشكى نمره اضطراب زيادى به دست آوردئد.

\section{مواد و روشها}

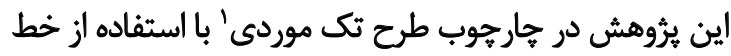

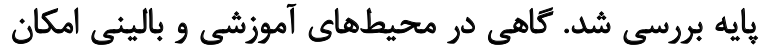

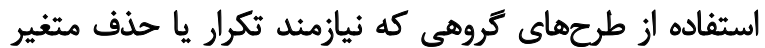

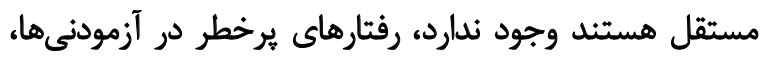

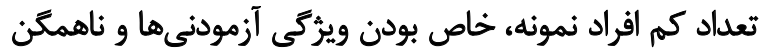

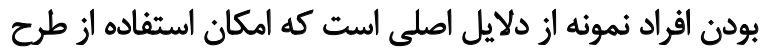

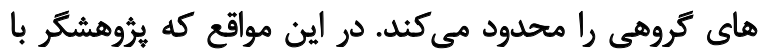

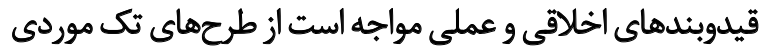

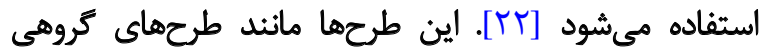

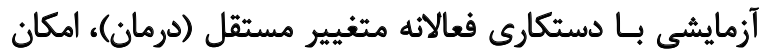

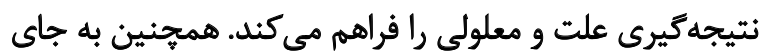

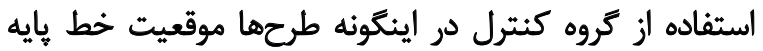

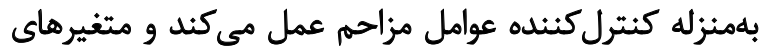

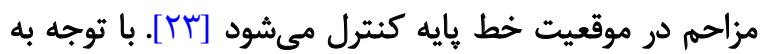

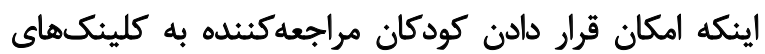

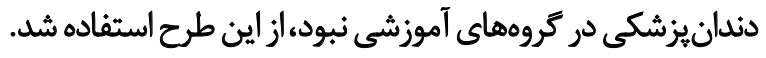

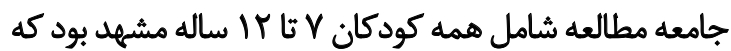

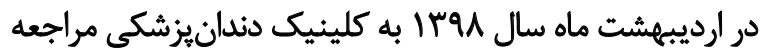

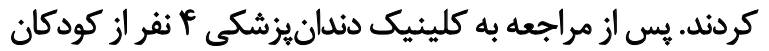

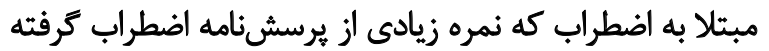

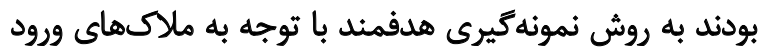

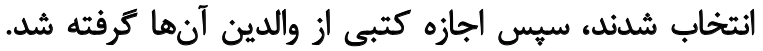

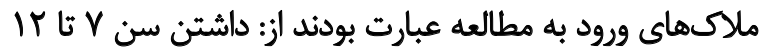

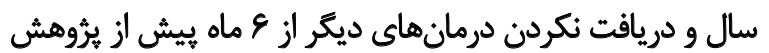

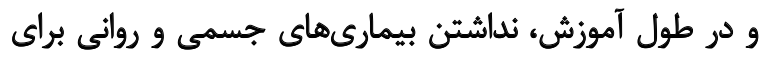

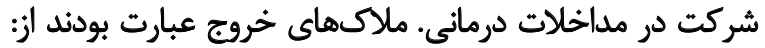

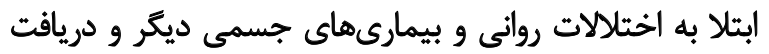

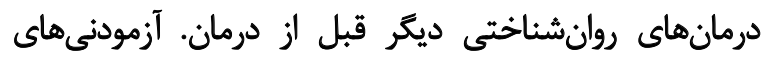

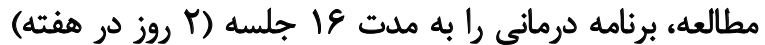

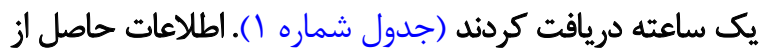

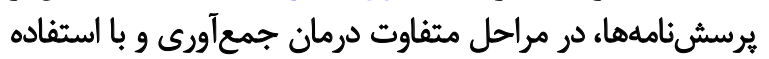

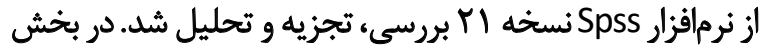

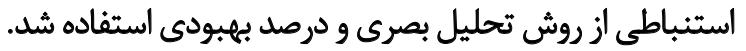

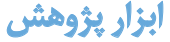

يرسشنامه نظهجويى شناختى هيجان فرم كودكان: اين

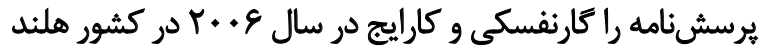

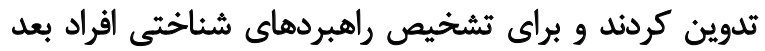

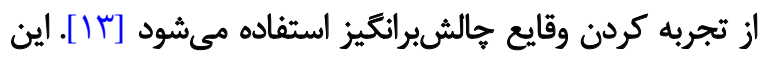

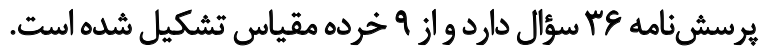


جدول ا. جلسات درمان Coping Cat

\begin{tabular}{|c|c|}
\hline محتواى دومان & جلسه \\
\hline برقرارى ارتباط و آشنايى با الهداف درمان & جلسه اول \\
\hline شناسايى احساس اضطراب، كمك به كودك براى شناخت احساس هاى مختلف و تشخيص تمايز احساس اضطراب و نكراتى & جلسه دوم \\
\hline شناسايى واكتش هاي بلدنى به اضطراب & جلسه سوم \\
\hline اولين جلسه هلاقات با والدين & جلسه جهارم \\
\hline آشنايع با تمرين آرميدكى و بهكاركيرى آن در كاهش تثنش عضلانى همراه با اضطراب & جلسه ينجم: \\
\hline شناسايي خودمويي اضطراب آور و يادكيرى به هالش كشيدن افكار & جلسه شُشم \\
\hline مرورى بر خودمويى اضطرابى و خودوكيى مقابله كرى و ايجاد مهارتهاي حل مسثله & جلسه هُقتم \\
\hline أموزش خودارزيابي و ياداش به خود و مرورى بر مهارتهاى أموختهشده & جلسه هشتم \\
\hline 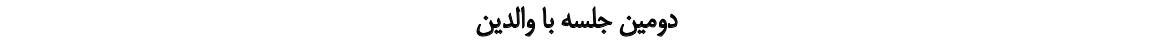 & جلسه نهم: \\
\hline ثمرين در موقعيتهايى كه داراى اضطراب كم هستند با استفاده از تكاليف در معرض قرار كرفتن & جلسه دهم \\
\hline تمرين در موقعيتهايى كه داراى اضطراب كم هستئده با استفاده از تكاليف در معرض قرار كرفتن & جلسيه يازدهم \\
\hline تمرين تكاليف مواجها در موقعيتهايى با اضطراب متوسط & جلسه دوازدهم \\
\hline آهوزش تكاليف مواجهه در موقعيتهاييى با اضطراب متوسط & جلسه سيزدهـم \\
\hline آموزش تكاليف هواجهه در هوقعيتهايى با اضطراب زياد & جلسه جهاردهم \\
\hline آهوزش تكاليف مواجهه در هواقعى كه اضطراب زيادى ايجاد مي شود & جلسه يائزدهم: \\
\hline تمرين تكاليف مواجها در موقعيتهايى با اضطراب زياد، ساخت يك أكمهى تبليغاتى و به بايان رساندن درمان & جلسه شانزدهم \\
\hline
\end{tabular}

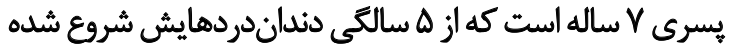

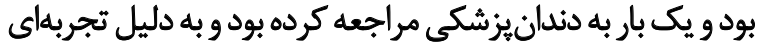

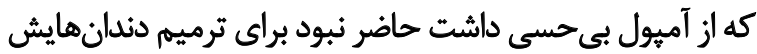

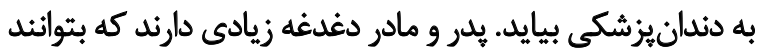

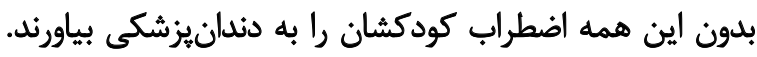

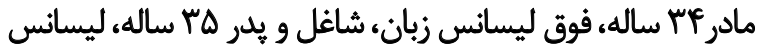

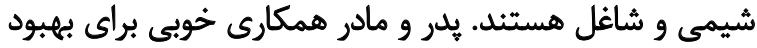
اضطراب كودكشان داشتند (تصاوير شماره بـ و ع).

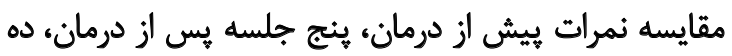

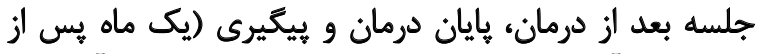

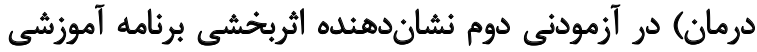

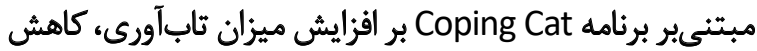

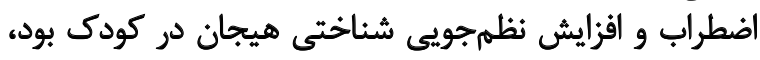
همجنين كاهش اضطراب كودى در مرحله يُيخيرى ادامه داشت دئ.
شيسى 9 ساله كه دورههاى اضطرابش از اول دبستان شروع شاره بود و اكنون كه به كلينيك دندانئيز

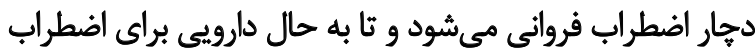

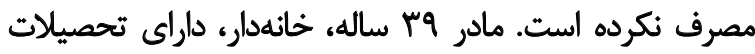

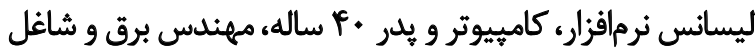

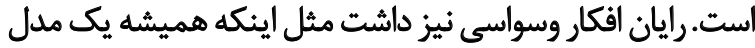

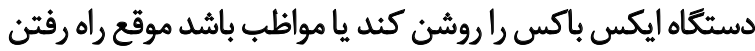
ياهايش روى خط موزائيكها نرود (تصاوير شماره إو و r).

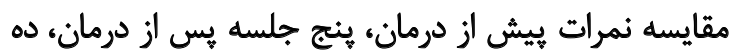

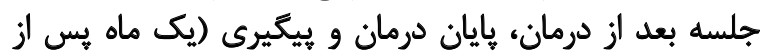

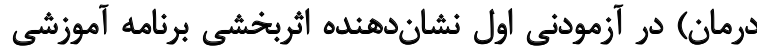

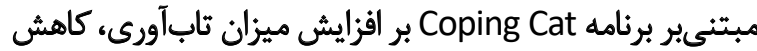

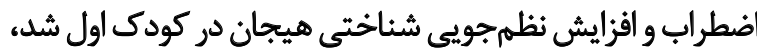

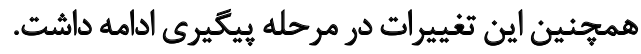




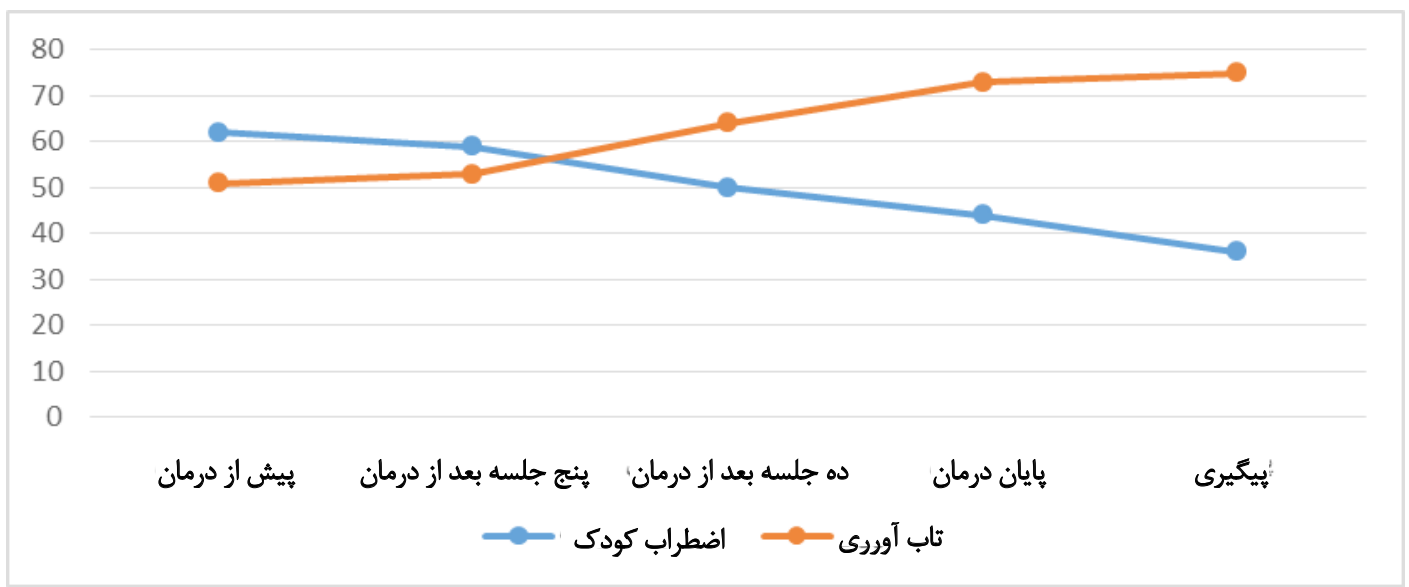

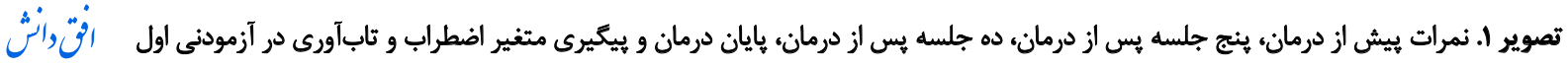

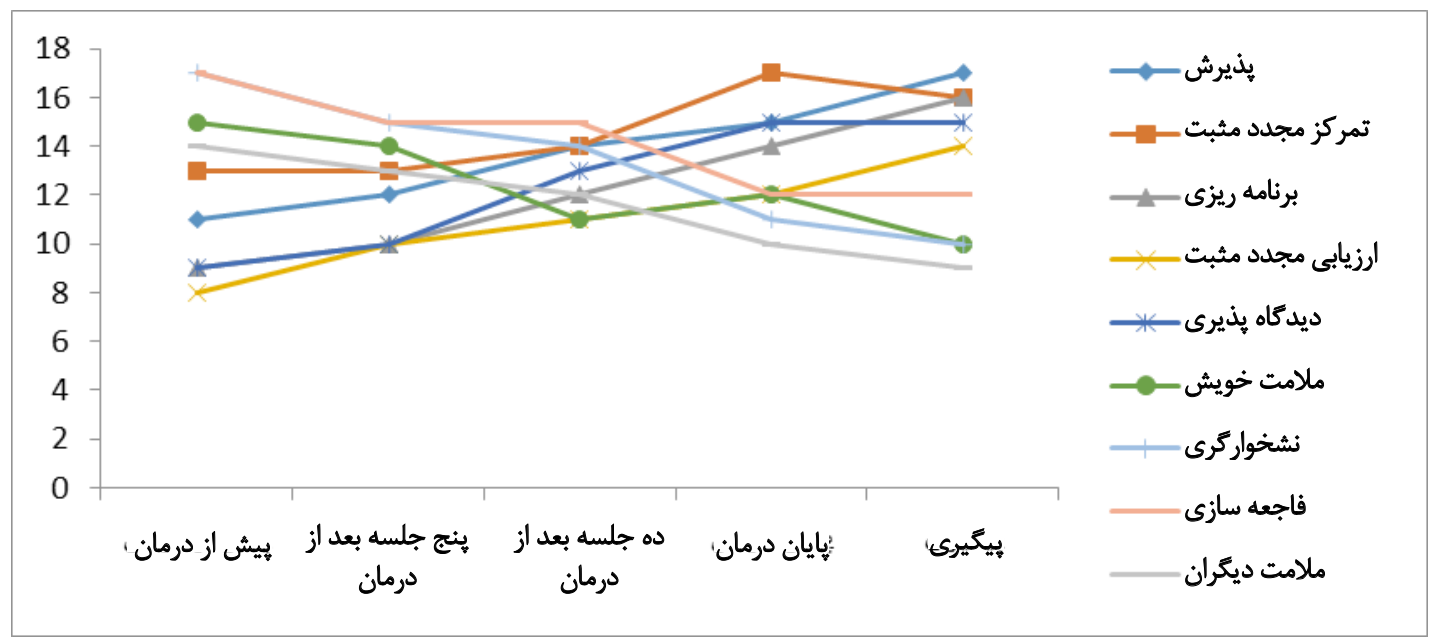

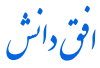

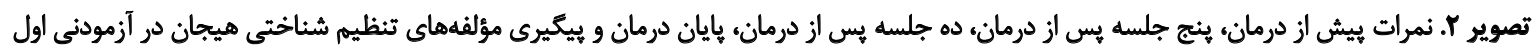

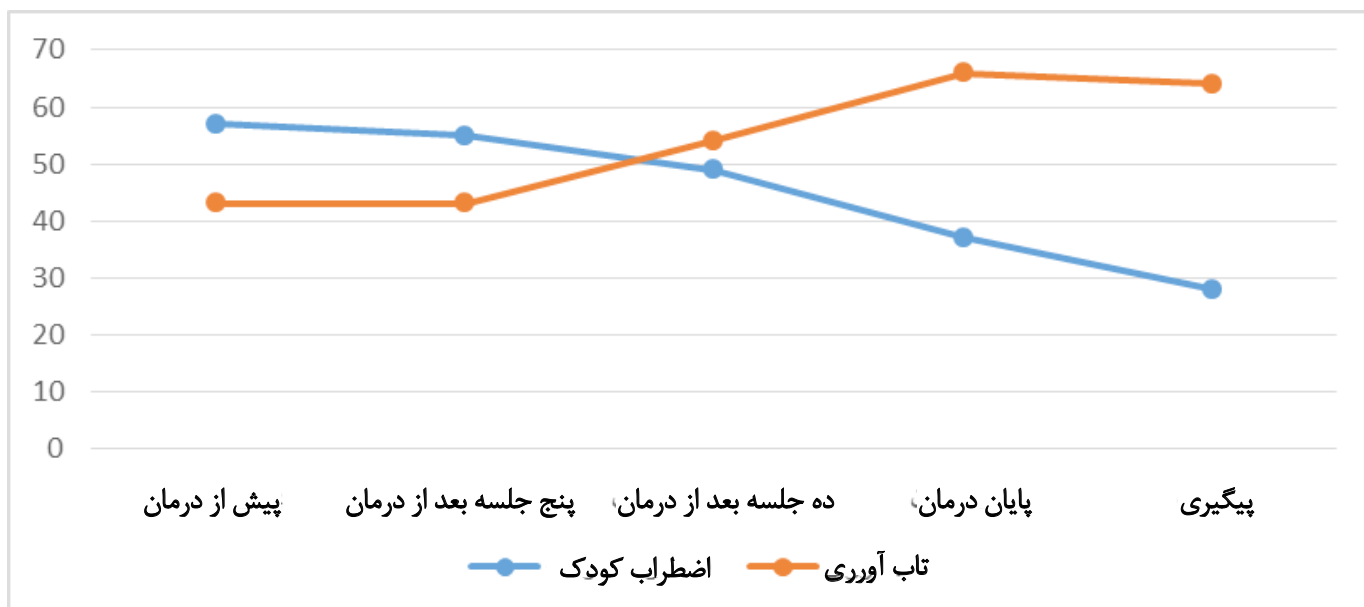

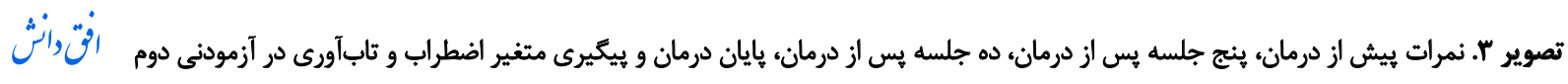




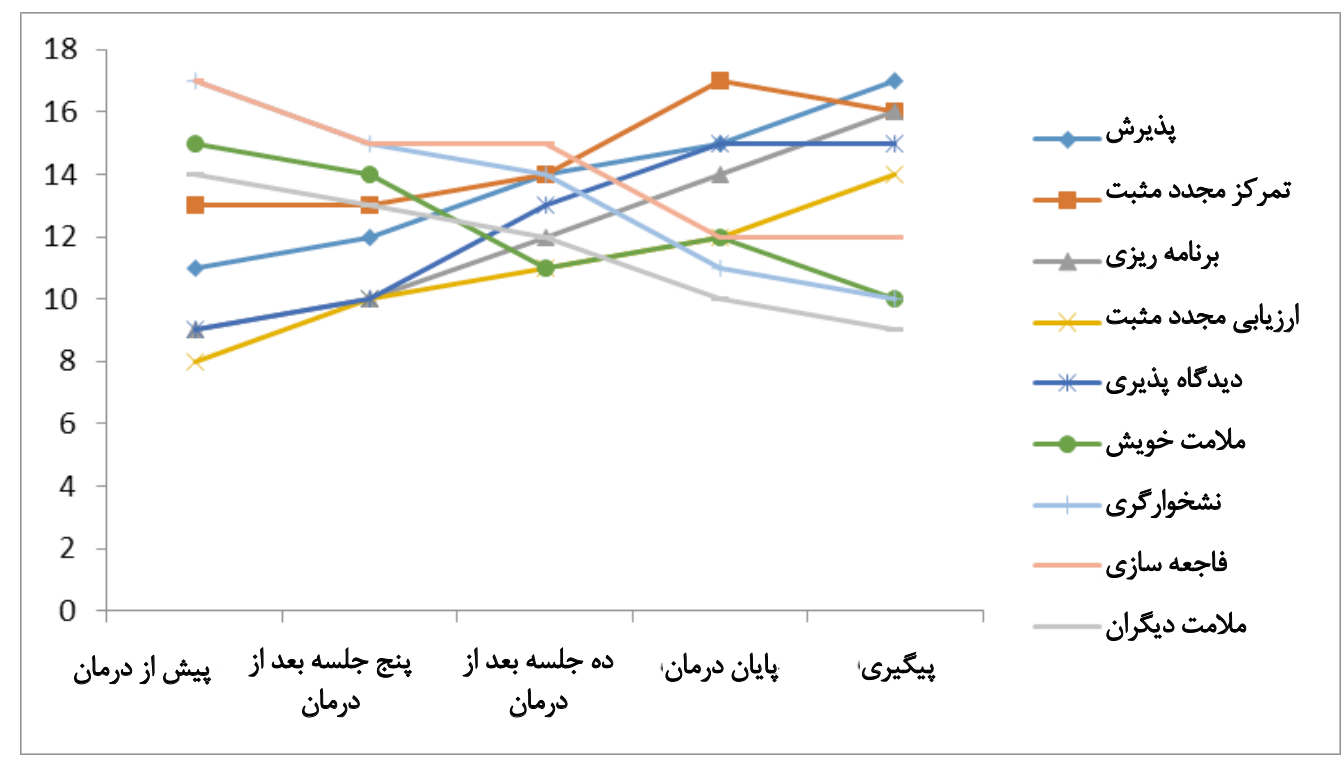

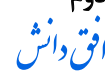

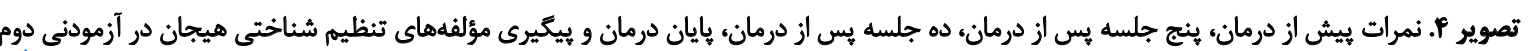

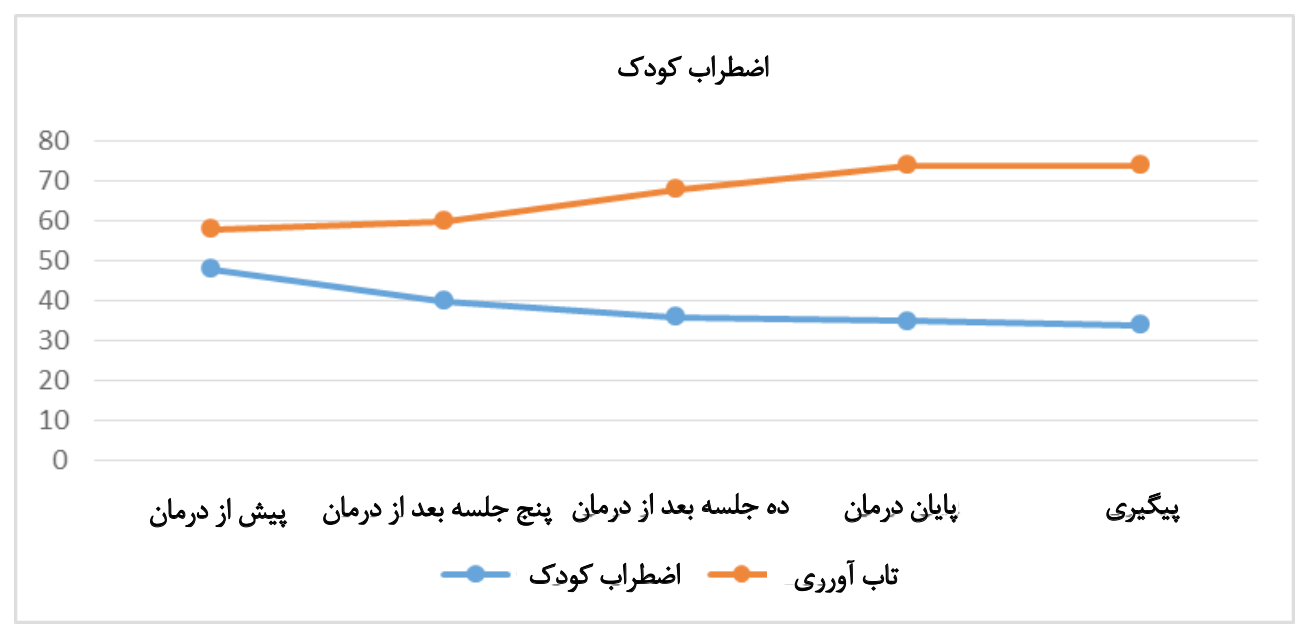

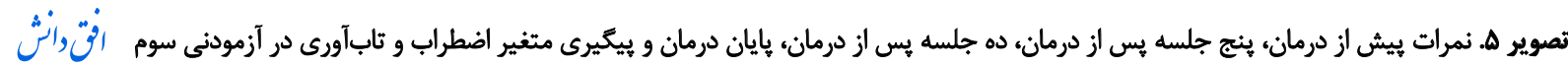

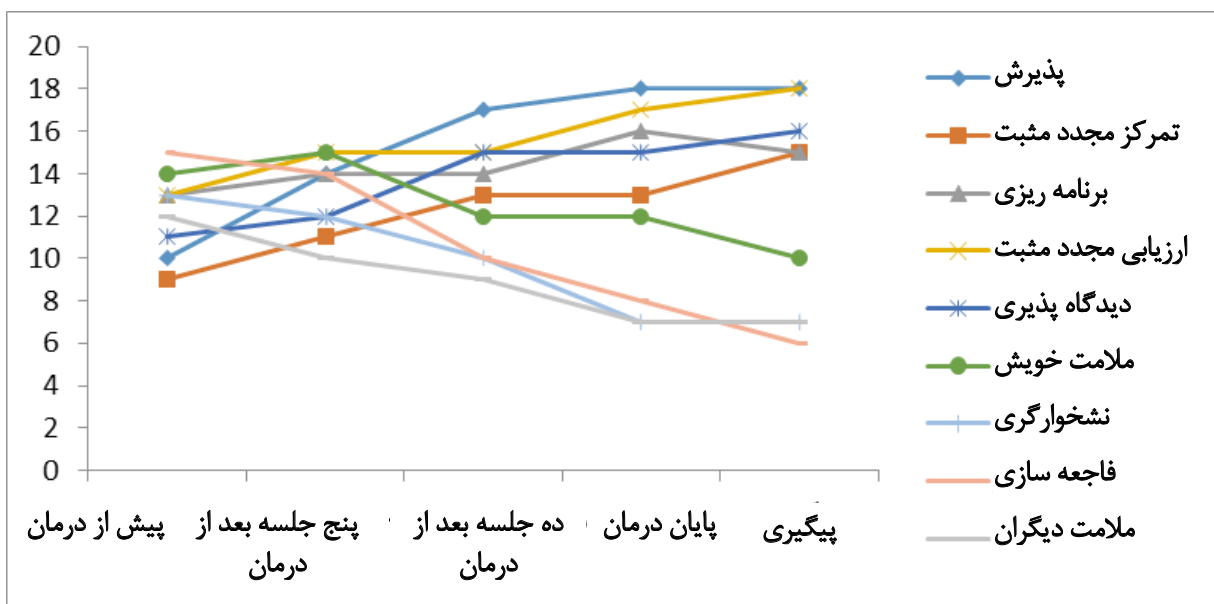

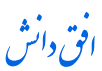

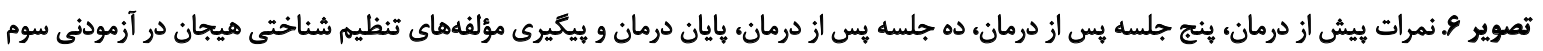




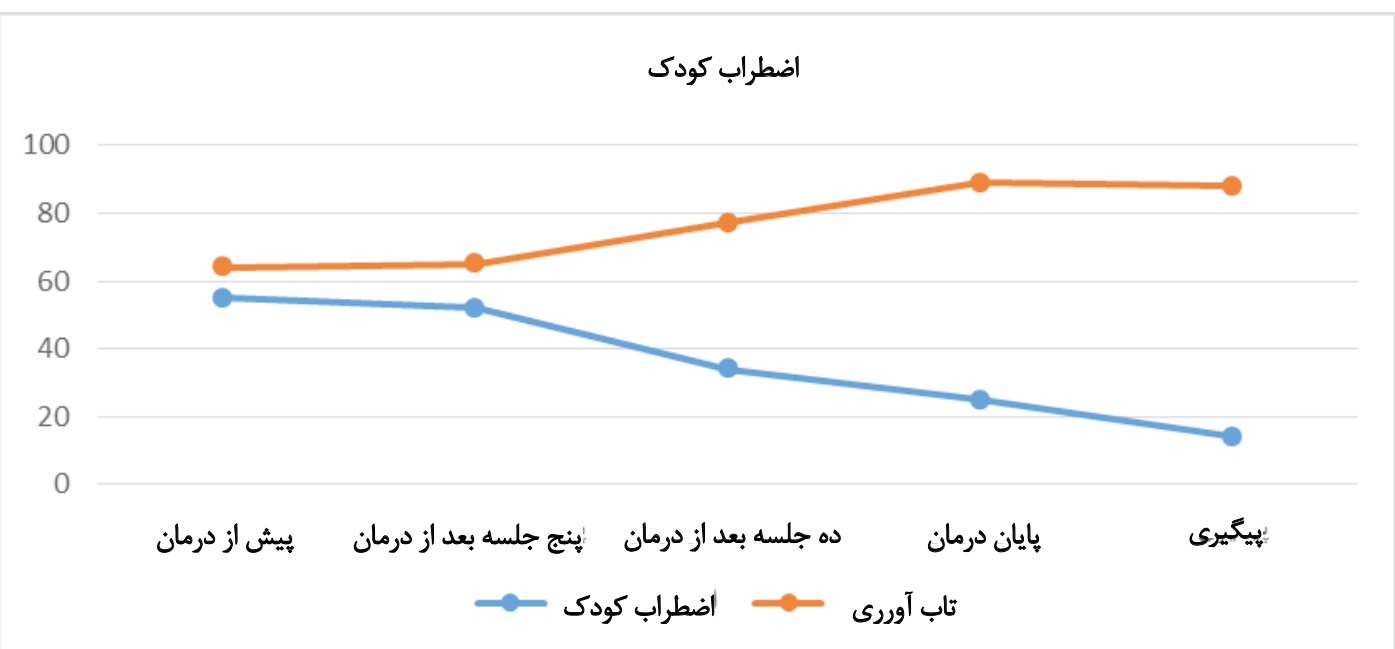

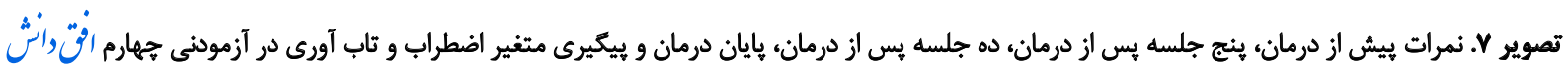

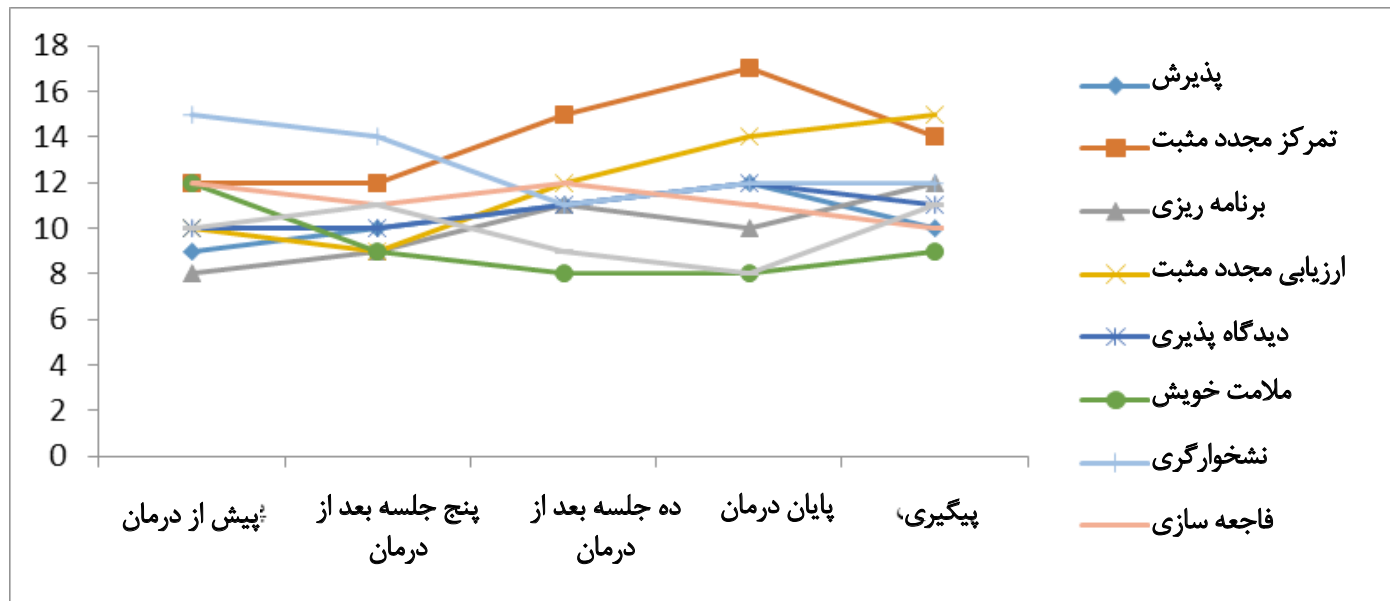

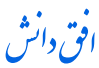

تصوير A. نمرات بيش از درمان، بئج جلسه بس از درمان، ده جلسه يس از درمان، بايان درمان و يبكيرى مؤلفهاى تنظيم شناختى هيجان در آزمودنى جهارم

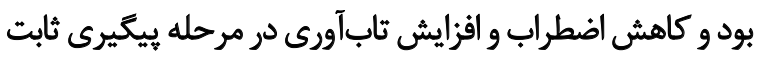

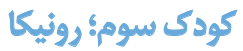

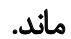

\section{كودى جهيار مة على}

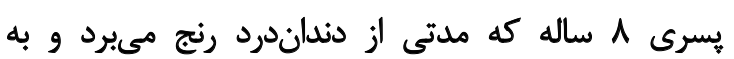

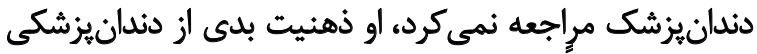

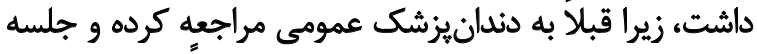

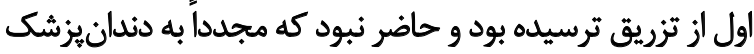

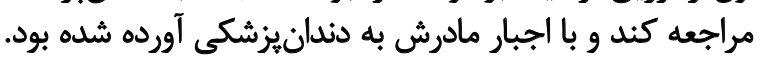

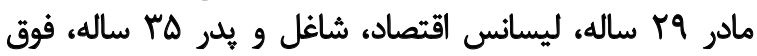

$$
\text { ليسانس اقتصاد و شاغل بود (تصاوير شماره لو و ^). }
$$

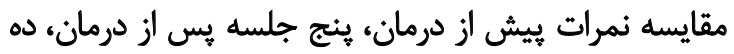

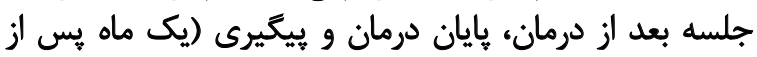

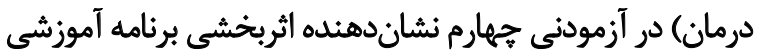

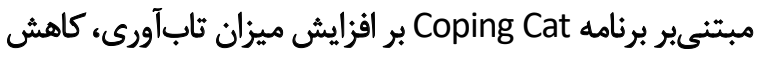

دخترى 9 ساله است كه تعدادى از دندانهاي شيرى اش هنوز

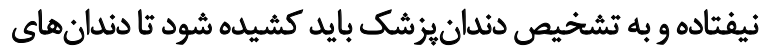

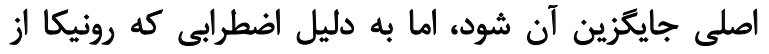

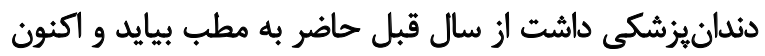

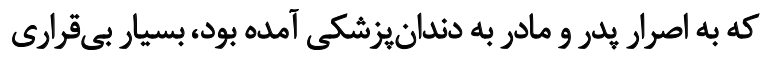

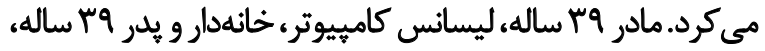

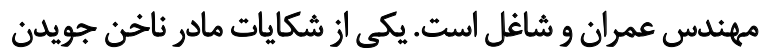
رونيكا بود كه در جلسات آخر درمان شد (تصاوير شماره هل هو 9).

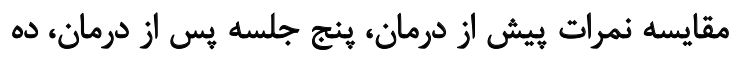

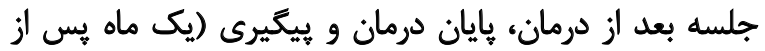

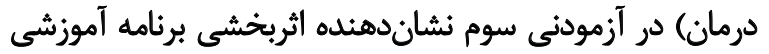

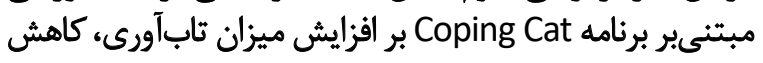
اضطراب و افزايش نظهمجيى شناختى هيجان در كودى سوم 
جدول r. نتّايج اندازه اثر در مراحل بايان درمان و بيكئيرى متغير اضطراب و تابآورى

\begin{tabular}{|c|c|c|c|}
\hline \multicolumn{2}{|c|}{ درصد } & \multirow{2}{*}{ مرحله } & \multirow{2}{*}{ أز هودنى ها) } \\
\hline ثاب أورى & اضطراب & & \\
\hline pr & rq & مرحله بايان درمان & \\
\hline pq & pi & ييكيرى & اول \\
\hline ar & ه & مرحله باياين درمان & \\
\hline PA & a. & ييكيرى & دوم \\
\hline r & r & مرحله بايان درمان & \\
\hline rf & rq & ييكيرى & سوم \\
\hline rq & af & هرحله بايان درمان & \\
\hline$r$ & $n^{e}$ & ييكيرى & جهارק \\
\hline
\end{tabular}

اقنّانث

اضطراب و افزايش نظمجويى شناختى هيجان در كودى بوده، بحث همجنين كاهش اضطراب كودى و افزايش ثاب آروى در مر مرحله

ترس و اضطراب در زندكى كودكان آثار كوناكونى از خود به

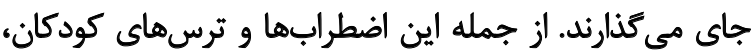

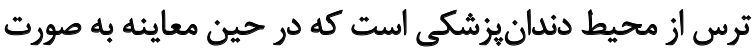

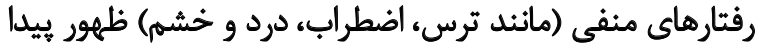

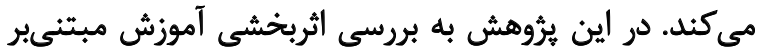

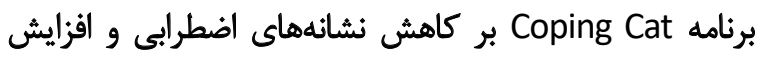

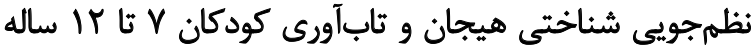

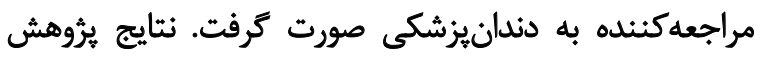

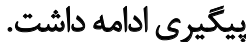

همان طور كه در جداول شماره r و ب مشاهده ميشود

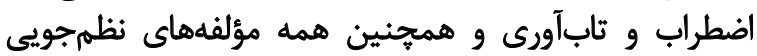

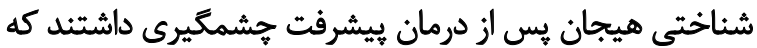

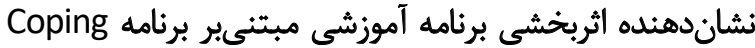

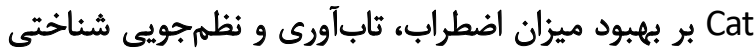

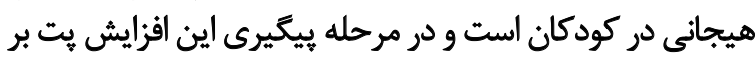
جا بوده است.

جدول r. نمرات خط هايه، درمان و ييكيرى در مقياس نظمجويى شئاختى هيجان

\begin{tabular}{|c|c|c|}
\hline \multicolumn{2}{|c|}{ درصد } & \multirow{2}{*}{ مقياس } \\
\hline بهيودى در بييكيرى & بهبودى يس از درمان & \\
\hline.$/ 100$ & . & يذّيرش \\
\hline ( & $\cdot / \mu r$ & تمركز مجدد مثبت \\
\hline.$/ \Delta V$ &.$/ \Delta r$ & برنامهريزى \\
\hline.$/ \pi V$ &.$/ \pi$ & ارزيابيى مجدد هثبت \\
\hline.$/ R A$ & - per & ديدكاهيذيرى \\
\hline.$/ R E$ &.$/ 19$ & ملامت خويشتن \\
\hline . & $\cdot / \pi V$ & نشخواركرى \\
\hline.$/ 18$ &.$/ A P$ & فاجعهuli \\
\hline .118 & . & ملامت ديكران \\
\hline
\end{tabular}

إنتوراتث 
و خودكويىهاى اضطرابى بر احساسات و رفتار، فهميدن وجود

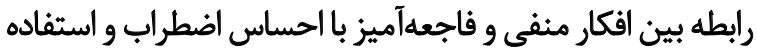

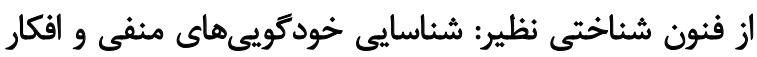

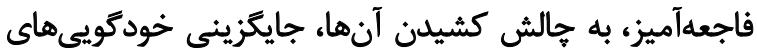

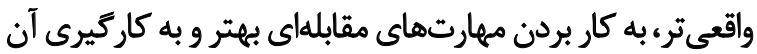

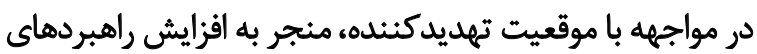

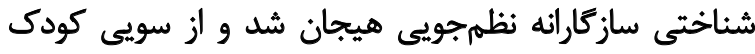

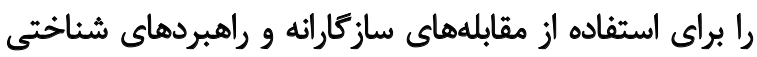

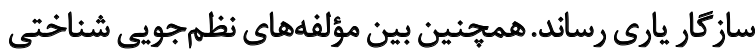

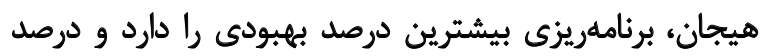

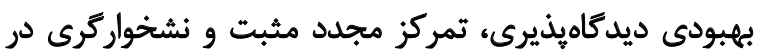
مرحله بيغيرى كاهش بيدا كرده است.

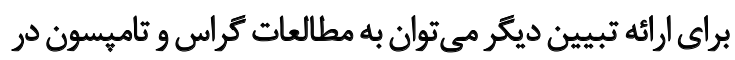

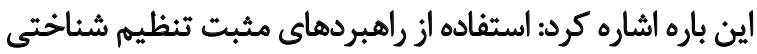

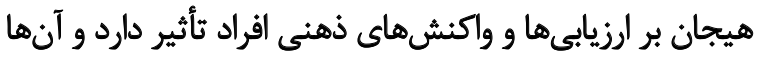

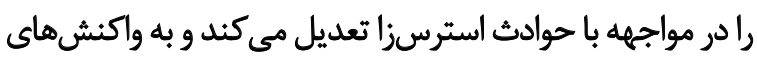

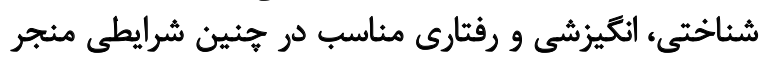

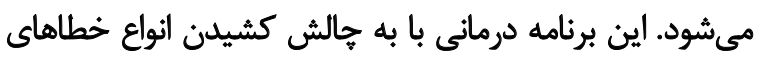

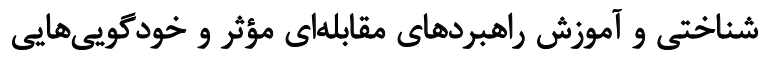

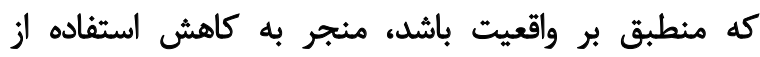

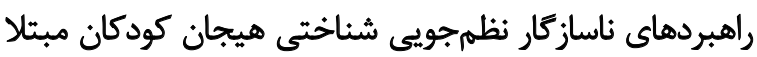

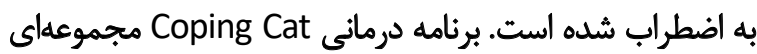

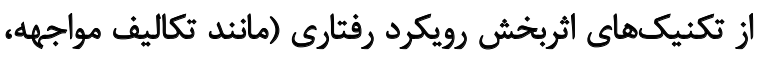

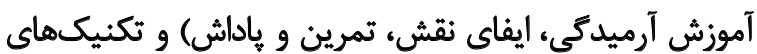

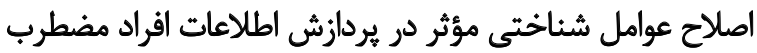

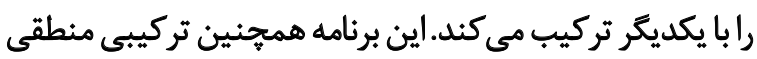

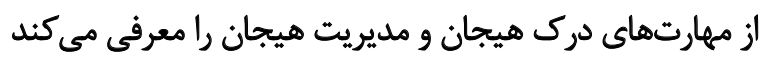

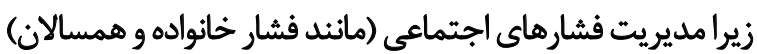

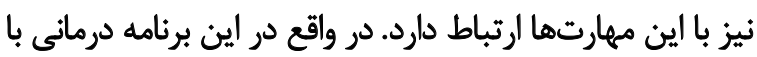

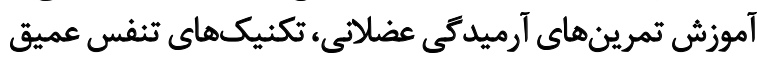

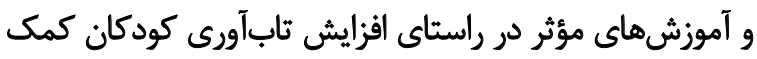
كرده است.

\section{نتيجهيَيرى}

در مجموع اين مطالعه نشان داد كه آموزش مبتنىبر برنامه Coping Cat

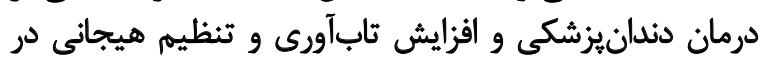

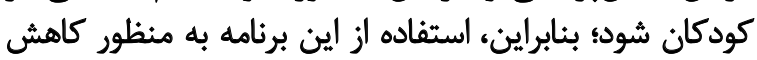

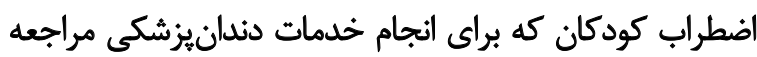

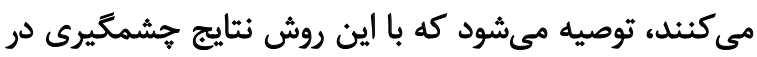
كاهش شدت اضطراب كودكان مي شئود.

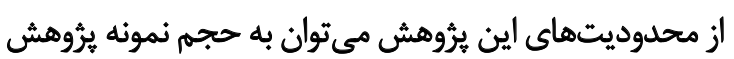

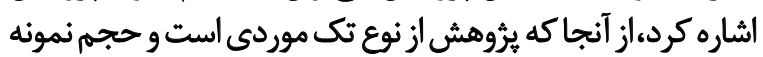

نشان داد كه آموزشى مبتنىبر برنامه Coping Cat باعث بهبود

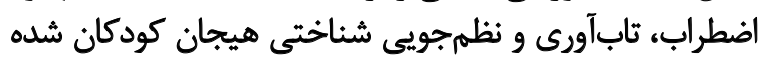

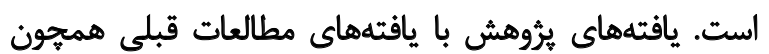

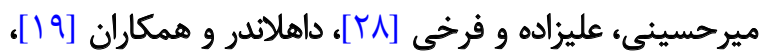

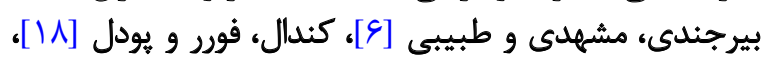

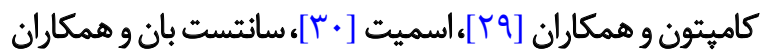

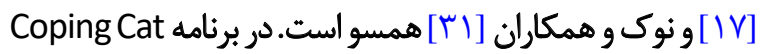

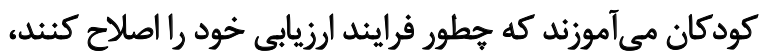

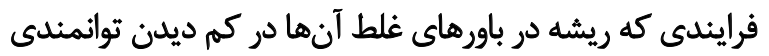

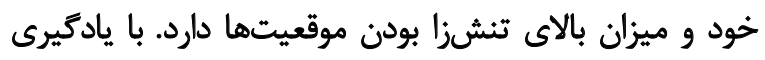

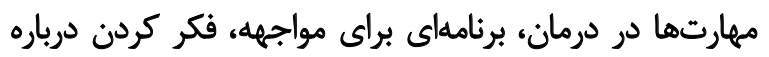

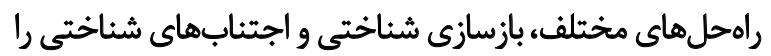

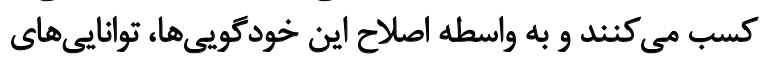

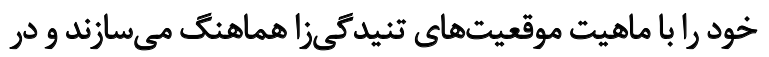

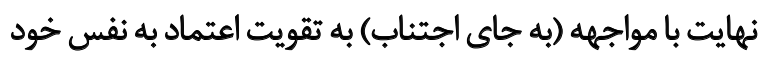

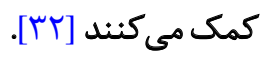

در تبيين نتايج حاضر مى توان جنينين بيان كرد كه در اين

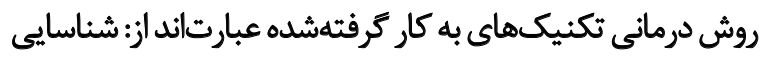

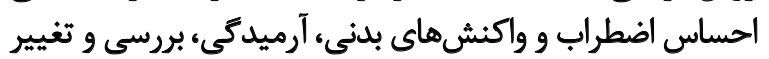

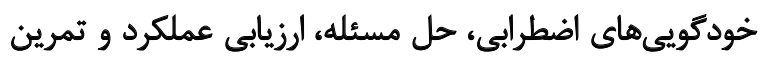

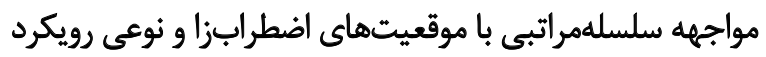

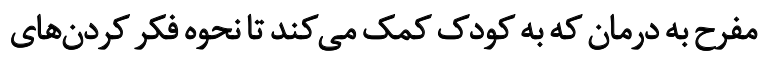

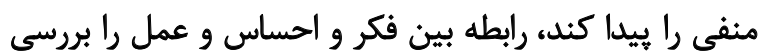

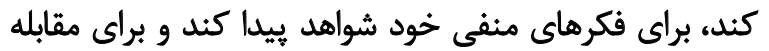

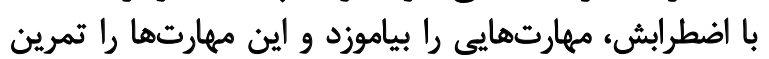

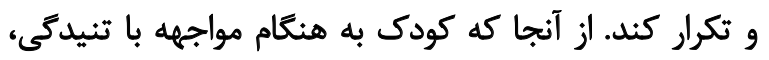

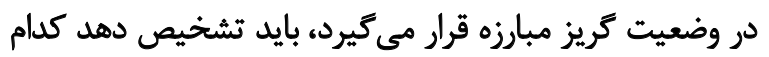

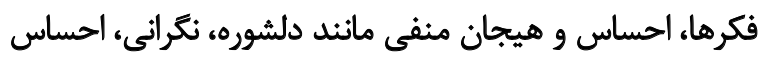

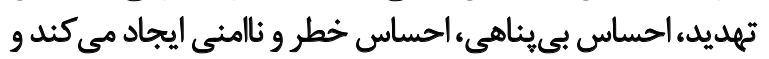

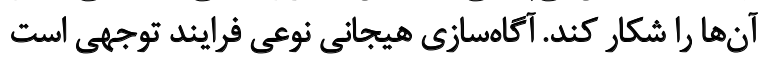

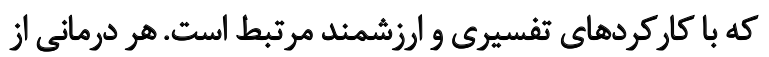

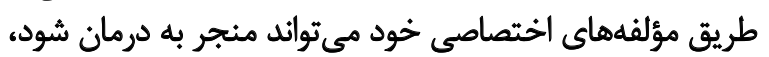

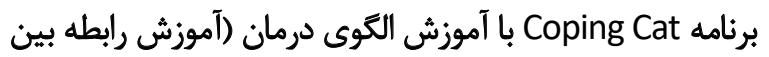

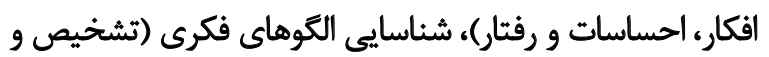

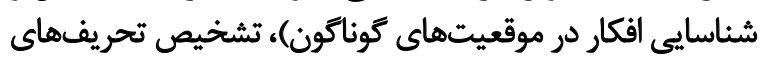

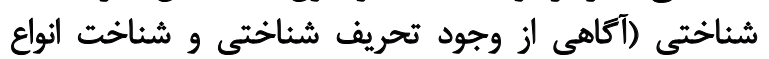

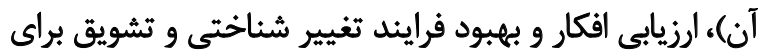

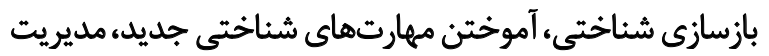

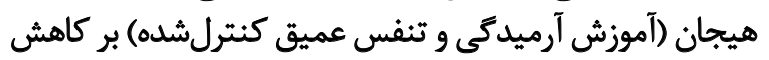

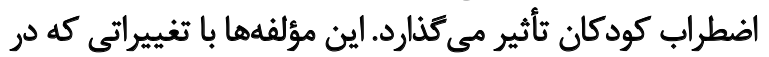

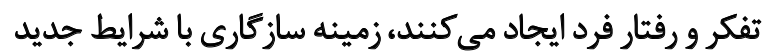

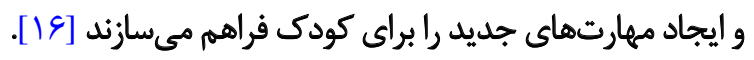

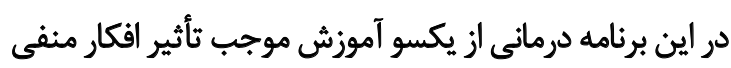




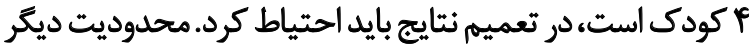

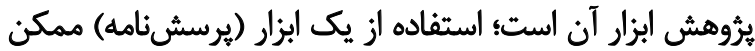

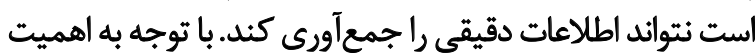

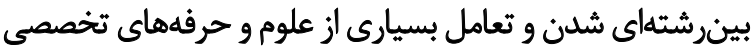

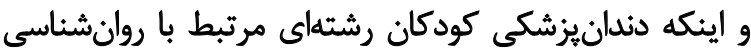

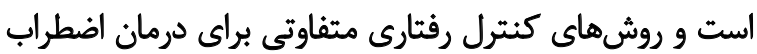

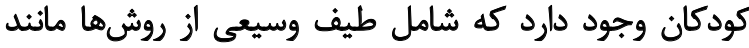

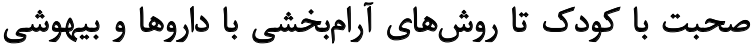

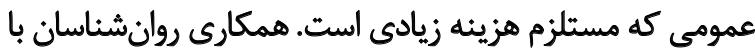

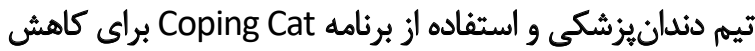

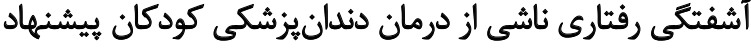

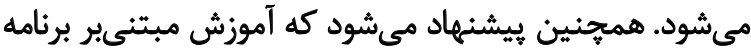

Coping Cat

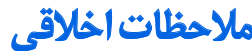

\section{يديروى أو أصول الخالاق بثوهش}

اين طرح در جلسه كميته منطقهاي اخلاق در يُروهش زيست

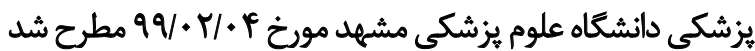

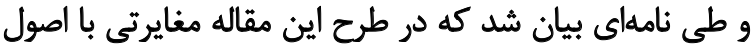
اخلاق در يروهش مشاهده نشده است

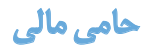

مقاله حاضر بركرفته از ياياننامه كارشناسى نويسنده اول در

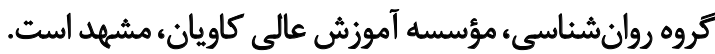

$$
\text { مشار كت ثويسند مكان }
$$

تمام نويسندكان در طراحى، اجرا و نكارش همه بخشهاى تيروهش حاضر مشاركت داشتهاند.

$$
\text { تعارض منافع }
$$

بنابر اظهار نويسندكان اين مقاله تعارض منافع ندارد. 


\section{References}

[1] Lin CS, Wu SY, Yi CA. Association between anxiety and pain in dental treatment: A systematic review and meta-analysis. Journal of Dental Research. 2017; 96(2):153-62. [DOI:10.1177/0022034516678168] [PMID]

[2] van Starrenburg ML, Kuijpers RC, Kleinjan M, Hutschemaekers GJ, Engels RC. Effectiveness of a cognitive behavioral therapy-based indicated prevention program for children with elevated anxiety levels: A randomized controlled trial. Prevention Science. 2017; 18(1):31-9. [DOI:10.1007/s11121-016-0725-5] [PMID]

[3] Vadiati Saberi B, Neshandaar Asli H, Sharifiyan HR. [Evaluation of dental anxiety level and related factors in patients referred to dental school (Persian)]. Journal of Guilan University of Medical Sciences. 2018; 27(106):9-16. http://journal.gums.ac.ir/article-1-1669-en.html

[4] Soares FC, Lima RA, de Barros MVG, Dahllöf G, Colares V. Development of dental anxiety in schoolchildren: A 2-year prospective study. Community Dentistry and Oral Epidemiology. 2017; 45(3):281-8. [DOI:10.1111/ cdoe.12290] [PMID]

[5] Gross JJ, Thompson RA. Emotion regulation: Conceptual foundations. In: Gross JJ, editor. Handbook of Emotion Regulation. New York: Guilford Press; 2007. pp. 3-24. https://books.google.com/ books?id=Jh81/ZKqFH8C\&dq

[6] Alizadeh Birjandi Z, Mashhadi A, Tabibi Z. [The effectiveness of coping cat program on improving emotion cognitive regulation among children with anxiety disorders (Persian)]. Clinical Psychology Studies. 2016; 6(24):153-73. [DOI:22054/JCPS.2016.6533]

[7] Hasani J. [The psychometric properties of the Cognitive Emotion Regulation Questionnaire (CERQ) (Persian)]. Journal of Clinical Psychology. 2010; 2(3):73-84. [DOI:10.1111/cdoe.12290]

[8] Mortazavi NS, Yarolahi NA. Meta-analysis of the relationship between resilience and mental health. Journal of Fundamentals of Mental Health. 2015; 17(3):103-8. [DOI:10.22038/JFMH.2015.4309v]

[9] Atadokht A, Norozi H, Ghaffari O. [The effect of social problem-solving training on psychological well-being and resiliency of students with learning difficulties (Persian)]. Journal of Learning Disabilities. 2014; 3(2):92-108. http://jld.uma.ac.ir/article_30.html

[10] Hjemdal O, Vogel PA, Solem S, Hagen K, Stiles TC. The relationship between resilience and levels of anxiety, depression, and obsessive-compulsive symptoms in adolescents. Clinical Psychology \& Psychotherapy. 2011; 18(4):314-21. [DOI:10.1002/cpp.719] [PMID]

[11] Fakhri MK, Hadizadeh Kafash R, Salimi M. [The effectiveness of cognitive-behavioral therapy on reducing the symptoms of anxiety in children (Persian)]. Paper presented at: $2^{\text {nd }}$ International Conference on Psychology, Educational and Behavioral Sciences. 10 July 2017; Iran, Tehran. https://www.sid.ir/Fa/Seminar/ViewPaper.aspx?ID=91571

[12] Wood JJ, Piacentini JC, Southam-Gerow M, Chu BC, Sigman M. Family cognitive behavioral therapy for child anxiety disorders. Journal of The American Academy of Child and Adolescent Psychiatry. 2006; 45(3):31421. [DOI:10.1097/01.chi.0000196425.88341.b0] [PMID]

[13] Garnefski N, Kraaij V. Relationships between cognitive emotion regulation strategies and depressive symptoms: A comparative study of five specific samples. Personality and Individual Differences. 2006; 40(8):1659-69. [DOI:10.1016/j.paid.2005.12.009]

[14] Edmund JM, Oneil KA, Kendall PC. A review of cognitive behavioral therapy for anxity disorders in children and adolescents: Cueeent status and future directions. Tidsskrift for Norsk Psykologforening. 2011; 48:26-33.
[15] Podell JL, Mychailyszyn M, Edmunds J, Connor M, Kendall PC. The coping cat program for anxity youth: The fear plan comes to Life. Cognitive and Behavioral Practice. 2010; 17(2):132-41. [DOI:10.1016/j.cbpra.2009.11.001]

[16] Zarghami F, Heydari Nasab L, Shaeiri MR, Shahrivar Z. [A study in the impact of coping-cat-based Cognitive-Behavior Therapy (CBT) on reduced anxiety in the children aged 8 to 10 with anxiety disorder (Persian)]. Clinical Psychology Studies. 2015; 5(19):183-202. https://jcps.atu. ac.ir/article_1514.html

[17] Santesteban-Echarri O, Hernández-Arroyo L, Rice SM, Güerre-Lobera MJ, Serrano-Villar M, Espín-Jaime JC, et al. Adapting the brief coping cat for children with anxiety to a group setting in the Spanish public mental health system: A hybrid effectiveness-implementation pilot study. Journal of Child and Family Studies. 2018; 27(10):3300-15. [DOI:10.1007/ s10826-018-1154-9]

[18] Kendall PC, Barmish AJ. Show-that-I-can (Homework) in cognitive-behavioral therapy for anxious youth: Individualizing homework for robert. Cognitive and Behaavioral Practice. 2007; 14(3):289-96. [DOI:10.1016/j. cbpra.2006.04.022]

[19] Dahlander A, Soares F, Grindefjord M, Dahllof G. Factors associated with dental fear and anxiety in children aged 7 to 9 years. Dentistry Journal. 2019; 7(3):68. [DOI:10.3390/dj7030068] [PMID]

[20] Mehrstedt M, Tönnies S, Eisentraut I. Dental fear, health status, and quality of life. Anesthesia Progress. 2004; 51(3):90-4. [PMID] [PMCID]

[21] Abrahamsson KH, Berggren U, Hakeberg M, Carlsson SG. Phobic avoidance and regular dental care in fearful dental patients: A comparative study. Acta Odontologica Scandinavica. 2001; 59(5):273-9. [DOI:10.1080 /000163501750541129] [PMID]

[22] Ledford JR, Gast DL. Single subject research methodology in behavioral sciences: Applications in special education and behavioral sciences. New York: Routledge; 2009. [DOI:10.1080/000163501750541129]

[23] Farahani HA, Abedi A, Agha Mohammadi S, Kazemi Z. [Methodology of individual case studies in behavioral and medical sciences (applied approach) (Persian)]. Tehran: Danjeh; 2010.

[24] Spence SH, Barrett PM, Turner C. Psychometric properties of the Spence Children's Anxiety Scale with young adolescents. Journal of Anxiety Disorders. 2003; 17(6):605-25. [DOI:10.1016/S0887-6185(02)00236-0]

[25] Mousavi R, Moradi AR, Farzad V, Mahdavi Harsini SE, Spence S, Navabinejad Sh. Psychometric properties of the Spence children's anxiety scale with an Iranian sample. International Journal of Psychology. 2007; 1(1):17-26. https://iranjournals.nlai.ir/handle/123456789/79731

[26] Ungar M, Liebenberg L. The Child and Youth Resilience Measure (CYRM). Halifax, NS: Resilience Research Center; 2009. https://resourcecentre.savethechildren.net/publishers/resilience-research-center

[27] Kazerouni Zand B, Sepehri Shamloo Z, Mirzaiyan B. [The study of psychometric features for Child and Youth Resilience Measure (CYRM-28) in Iranian society: Validity and reliability (Persian)]. Quarterly Journal of Health Breeze. 2013; 2(3):15-21. http://jfh.iausari.ac.ir/article_641848. html

[28] Shokri Mirhosseini H, Alizade H, Fasrrokhi N. [The impact of coping cat program on symptoms reduction in children with anxiety disorders. (Persian)]. Journal of Child Mental Health. 2018; 5(2):1-13. http://childmentalhealth.ir/article-1-323-fa.htm

[29] Compton SN, March JS, Brent D, Albano AM, Weersing VR, Curry J. Cognitive-behavioral psychotherapy for anxiety and depressive disorders in children and adolescents: An evidence-based medicine review. 
Journal of the American Academy of Child \& Adolescent Psychiatry. 2004; 43(8):930-59. [DOI:10.1097/01.chi.0000127589.57468.bf]

[30] Smith BN. School-based implementation of abbreviated coping cat program to reduce behavioral symptoms of anxious children [MS. thesis]. Greenville, NC: East Carolina University; 2017. http://hdl.handle. net/10342/6134

[31] Nook EC, Vidal Bustamante CM, Cho HY, Somerville LH. Use of linguistic distancing and cognitive reappraisal strategies during emotion regulation in children, adolescents, and young adults. Emotion. 2020; 20(4):525-40. [DOI:10.1037/emo0000570] [PMID]

[32] Dadsetan P, Tehranizadeh M, Rasolzadeh Tabatabaye K, Azadfallah P, Fathi-Ashtiany A. [The effectiveness of Kendall's coping cat protocol on coping strategies of Iranian children afflicted with internalized disorders (Persian)]. Journal of Research in Psychological Health. 2009; 3(3):59-68. http://ensani.ir/fa/article/219125 
This Page Intentionally Left Blank 